\title{
Realizacje idei „miasta-ogrodu” w międzywojennej Polsce na przykładzie Podkowy Leśnej oraz Kolonii Letniej Żarki
}

\author{
Słowa kluczowe: miasto-ogród, Ebenezer Howard, parcelacja, II Rzeczpospolita, \\ Karol Raczyński, Żarki, Podkowa Leśna \\ Key words: garden city, Ebenezer Howard, parcelling, inter-war Poland, \\ Karol Raczyński, Żarki, Podkowa Leśna
}

I. Narodziny idei „miasta-ogrodu”. II. Zainteresowanie projektem na ziemiach polskich.

III. Podkowa Leśna. IV. Kolonia Letnia Żarki. V. Zakończenie

Celem niniejszego artykułu będzie porównawcza analiza międzywojennych parcelacji realizowanych w oparciu o koncepcję „miasta-ogrodu”, w wyniku których powstały m.in. sławna podwarszawska Podkowa Leśna oraz mniej znana, położona w ówczesnym województwie kieleckim, Kolonia Letnia Żarki (obecnie Żarki Letnisko). W centrum zainteresowania znajdą się następujące kwestie: okoliczności towarzyszące powstawaniu miejscowości, rozwiązania formalno-prawno-organizacyjne przyjęte w fazie realizacji projektów, planowany kształt przestrzenny osad, tempo sprzedaży działek i zasiedlania miejscowości, stopień ich infrastrukturalnego zaawansowania do wybuchu II wojny światowej, a także skala ujawnionej społecznej aktywności ich mieszkańców. Zestawienie to pozwoli rozpoznać zarówno specyficzne cechy oraz uwarunkowania każdej z rozpatrywanych realizacji „miasta-ogrodu”, jak i określić ich wspólne elementy występujące w poszczególnych fazach urzeczywistniania koncepcji. Ukazanie tych dość głośnych swego czasu w skali kraju i regionu inicjatyw na szerszym tle społeczno-gospodarczym pozwoli także na sformułowanie bardziej ogólnych wniosków odnośnie do możliwości, szans i wyzwań wdrażania tego rodzaju projektów w Polsce międzywojennej.

\section{Narodziny idei „miasta-ogrodu”}

Zasadniczym punktem odniesienia dla wspomnianych projektów przestrzenno-architektonicznych będą założenia powstałej w końcu XIX w. idei „miasta-ogrodu”. Ebenezer Howard stworzył ją jako alternatywę dla przeludnionych i chaotycznie rozrastających się w czasach industrializacji ośrodków miejskich, których liczba mieszkańców dochodziła do setek tysięcy lub nawet kilku milionów (jak chociażby w Paryżu lub największym z nich Londynie) ${ }^{1}$. Znaczący odsetek przybyłej tam za pracą ludności żył w skrajnej nędzy i niezwykle trudnych, rujnujących zdrowie warunkach lokalowych, wynajmując obskurne, często pozbawione słońca, ciasne i wilgotne izby stawianych naprędce domów. Gęsto zabudowane, spowite szaro-czarnymi, wydobywającymi się z fabrycznych kominów dymami dzielnice robotnicze stawały się

\footnotetext{
${ }^{1}$ Więcej o rozwoju europejskich miast i ich liczebności zob.: Davies N. 2004, s. 832, 1302.
} 
siedliskiem społecznej i moralnej deprawacji, której najczęstszymi przejawami były przestępczość, prostytucja i alkoholizm. Wśród londyńskich niechlubny prym wiodła położona na East Endzie Whitechapel, której mroczne okolice w 1888 r. wybrał na miejsce swoich okrutnych zbrodni nigdy nieujęty seryjny morderca zwany Kubą Rozpruwaczem².

Howard był stenografem brytyjskiego parlamentu, a jednocześnie nastawionym empatycznie myślicielem głęboko poruszonym obserwowaną niesprawiedliwością i krzywdą najbiedniejszych londyńczyków, przy tym krytycznie odnoszącym się do ówczesnych angielskich stosunków własnościowych. Zaproponował więc swoiste remedium, które jego zdaniem mogło uzdrowić chorą sytuację, objawiającą się nierównowagą pomiędzy skrajnie przeludnionymi miastami i coraz bardziej pustoszejącymi osadami wiejskimi ${ }^{3}$. Koncept polegał na utworzeniu zupełnie nowych, zdrowych, zakładanych (niczym średniowieczne wsie) na tzw. „surowym korzeniu” ośrodków miejskich o dość specyficznych kształcie, organizacji i funkcjach, które określił mianem „miast-ogrodów”. Szczegółowe przemyślenia dotyczące ich planistycznej wizji, źródeł finansowania, administrowania i wewnętrznego urządzenia przedstawił w książce wydanej po raz pierwszy w 1898 r. pod tytułem To-morrow. A Peaceful Path to Real Reform [Jutro. Pokojowa droga do prawdziwych reform], a po raz drugi w 1902 r. pod zmienionym tytułem Garden Cities of To-morrow [Miasta-ogrody jutra], przywołującym już bezpośrednio kluczowe określenie pomysłu. Praca ta w znaczący sposób przyczyniła się do szybkiej międzynarodowej popularyzacji odważnego projektu ${ }^{4}$. We wstępie Howard przytoczył wybrane, utrwalone w publicznej świadomości wypowiedzi nawołujące do pilnej zmiany istniejącego stanu rzeczy, jak chociażby opinię sformułowaną przez ówczesnego dziekana katedry w Canterbury Frederica Williama Farrara: „Stajemy się krajem wielkich miast. Wsie przestały się rozwijać lub wprost się kurczą, a miasta rosną na potęgę. Jeśli to prawda, że wielkie miasta stopniowo zmieniają się w nagrobki naszego gatunku, to czy można się temu dziwić, patrząc na domy tak wstrętne, zapuszczone, źle skanalizowane i zrujnowane przez zaniedbanie i brud?”5.

Specyficzną cechą nowych osad miało być harmonijne połączenie lub też „pożenienie”, jak to określał sam autor, miasta z wsią. Powstająca z takiego „związku” optymalna przestrzeń („miasto-wieś”) skupiałaby zalety zarówno jednego, jak i drugiego miejsca, przy jednoczesnej eliminacji wad każdego z nich. Te swoiście hybrydowe struktury zajmować miały dość rozległy, mierzący sześć tysięcy akrów (ok. 2,428 ha) obszar, który dzielił on na dwie zasadnicze części. Mniejsza (zajmująca jedną szóstą ogólnej powierzchni), centralnie położona, miała miejski charakter i stanowiła właściwe „miasto-ogród”6. Większość jej terenów przeznaczono na dzielnice mieszkaniowe (domy z ogrodami), ogród, parki, bulwary, aleje oraz gmachy publiczne z ratuszem, biblioteką, muzeum, teatrem i Kryształowym Pałacem, czyli szklanym pasażem handlowo-usługowym ${ }^{7}$. Na jej obrzeżach, zaplanowanych w postaci zewnętrznego okalającego pasa, pozostawiono miejsce na fabryki (z wymogiem zasilania wyłącznie czystą energią elek-

2 O Kubie Rozpruwaczu jako swoistym uosobieniu londyńskiego East Endu, zob.: Begg P. 2010, s. 11-15 (dalej odnoszący się do XIX w. opis dzielnic tej części Londynu).

3 „Wybrałem się w zatłoczone części Londynu i kiedy przechodziłem ciemnymi wąskimi ulicami, widziałem straszliwe mieszkania, w których mieszka większość ludzi, obserwowałem z jednej strony manifestacje oddolnego poszukiwania porządku i rozmyślałem na temat absolutnej niesprawiedliwości naszego systemu ekonomicznego, nagle naszło mnie wszechogarniające przekonanie o czasowości wszystkiego, co zobaczyłem, i przeświadczenie o całkowitej nieodpowiedniości tego dla życia pracą w nowym porządku — porządku sprawiedliwości, jedności i przyjaźni”, Leśniak-Rychlak D. 2015, s. 13.

${ }^{4}$ Leśniak-Rychlak D. 2015, s. 14.

5 Howard E. 2015, s. 29.

${ }^{6}$ Na specjalnych diagramach zamieszczonych w pracy Howarda, prezentujących w czytelny sposób schemat „miasta-ogrodu”, część miejska wpisana została w okrąg, Howard E. 2015, s. 40.

${ }^{7}$ Część sporej powierzchni Kryształowego Pałacu (budynek ten okalać miał w całości liczący 58 ha powierzchni Park Centralny) zaplanowano jako ogród zimowy, Howard E. 2015, s. 39. 
tryczną), wytwórnie, składy i magazyny. Zamykała tę część kolej obwodowa zapewniającą dogodną łączność pomiędzy wszystkimi dzielnicami. Za nią dopiero rozpościerała się część rolnicza składająca się farm, pastwisk, plantacji owoców, ogródków działkowych i lasów. Docelowa liczba ludności „miasta-ogrodu” szacowana była na 32 tysiące mieszkańców. Większość z nich miała znaleźć zatrudnienie w różnych gałęziach wytwórczości rolnej, w handlu, rzemiośle oraz wspomnianych fabrykach ${ }^{8}$. Twórca tego nowego organizmu przewidywał, iż zamieszkiwanie w tym wyjątkowym, przestronnym miejscu wyzwoli w mieszkańcach niespotykaną w „tradycyjnych” miastach aktywność skierowaną ku pracy na rzecz wspólnego dobra: „W każdej postępowej społeczności istnieją stowarzyszenia i organizacje przejawiające ponadprzeciętną inicjatywę i troskę o dobro publiczne. Samorząd mający władzę nad dowolną społecznością prawdopodobnie nie jest w stanie osiągnąć wyższego niż przeciętny poziom oczekiwań owej wspólnoty. Dobrobytowi społecznemu sprzyjałaby sytuacja, w której władze państwowe bądź samorząd do szybszego działania inspirują jej członkowie, których ideały zaangażowania społecznego wyrastają ponad przeciętność. Tak właśnie może być w mieście-ogrodzie. Pojawi się tam mnóstwo okazji do służenia dobru publicznemu, z których istoty z początku ani cała społeczność, ani nawet większość jej członków nie będzie zdawała sobie sprawy czy umiała skorzystać. Bezużyteczne byłyby też próby podjęcia takich działań przez samorząd. Ci którym leży na sercu dobro społeczeństwa, oddychając wolnym powietrzem miasta, zawsze jednak mogliby podejmować na własną odpowiedzialność eksperymenty, które wzmogą świadomość i zbudują społeczne zrozumienie"

Realizacje idei „miast-ogrodów” doprowadzić miały nie tylko do zasadniczej jakościowej poprawy warunków mieszkaniowych robotników, ale także, w co głęboko wierzył Howard, w dalszej perspektywie czasowej do ustanowienia nowej, lepszej i sprawiedliwszej rzeczywistości społecznej: „[...] zaspokojenie tej najpilniejszej potrzeby chwili uprości rozwiązanie wielu innych problemów, które do tej pory wystawiały na próbę pomysłowość największych myślicieli i reformatorów naszych czasów. Tak, rozwiązanie kwestii przywrócenia ludności na naszą wieś - piękną wieś, sklepioną niebem, owiewaną powietrzem, ogrzewaną słońcem, zwilżaną deszczem i rosą, ucieleśnienie boskiej miłości do człowieka — jest wręcz uniwersalnym kluczem. Wystarczy otworzyć za jego pomocą wrota i nawet lekko je uchylić, aby wdarła się fala światła, która rozjaśni problem pijaństwa, przepracowania, bezustannego niepokoju i dotkliwej biedy, granice ingerencji państwa, a nawet relację człowieka z Siłą Wyższą"10.

Oczekiwania Howarda w tym zakresie nie ziściły się jednak. Już samo zakładanie pierwszych „miast-ogrodów” napotykało na poważne przeszkody wymuszające kompromisy skutkujące częściowym wypaczeniem pierwotnych założeńn ${ }^{11}$. Pod wpływem tych doświadczeń koncepcja „miasta-ogrodu” ewoluowała. Coraz częściej zawężano ją już tylko do propozycji urządzania przedmieść istniejących miast, bądź też do tworzenia nowych podmiejskich kolonii ${ }^{12}$.

${ }^{8}$ Howard E. 2015, s. 42-43.

9 Howard E. 2015, s. 89.

${ }^{10}$ Howard E. 2015, s. 31.

11 Pierwsze „miasta-ogrody” zbudowane w Anglii za życia pomysłodawcy idei to położone w odległości ok. 50 km od Londynu Letchworth (inauguracja w 1909 r., do niego sprowadził się Howard) oraz nieco późniejszy Welwyn (1920 r.). Z powodu wyższych, niż przewidywały to szacunki Howarda, opłat podatkowo-czynszowych, Letchworth było za drogie dla robotników. Zamieszkiwali go więc głównie przedstawiciele wolnych zawodów i wysoko wykwalifikowani rzemieślnicy, Leśniak-Rychlak D. 2015, s. 18-19.

12 W deklaracji z 1909 r. angielskiego towarzystwa promującego inicjatywę „miasta-ogrodu” (Garden Cities and Town Planning Association) wymienia się już trzy formy jej realizacji: „,miasto-ogród”, „przedmieście-ogród” oraz „wieś/osada-ogród”. Tym ostatnim terminem określano osady przyfabryczne, które zakładali filantropijnie nastawieni przemysłowcy, Czyżewski A. 2001, s. 102-103. O recepcji idei „miasta-ogrodu” (zwłaszcza pod postacią „przedmieścia-ogrodu”) w Niemczech, zob.: Grzeszczuk-Brendel H. 2012, s. 96-103. 


\section{Zainteresowanie projektem na ziemiach polskich}

Na ziemiach polskich pierwsza fala zainteresowania ideą „miasta-ogrodu” przypadła na lata poprzedzające wybuch pierwszej wojny światowej ${ }^{13}$. Zgodnie z jej założeniami miały być parcelowane dwa podwarszawskie tereny: Ząbki — posiadłość hrabiego Adama Ronikiera oraz Młociny. Rok 1914 raptownie przerwał jednak te przedsięwzięcia i obie parcelacje nie wyszły poza fazę architektonicznych projektów ${ }^{14}$. W latach międzywojnia powrócono do pomysłu „miasta-ogrodu” jako jednej z liczących się propozycji w dyskusjach o kształcie i kierunkach rozwoju odrodzonej Polski. Znalazł on bowiem swoich oddanych entuzjastów i propagatorów wśród architektów, lekarzy, higienistów i społeczników. W publicznej świadomości rozpowszechnił się jednak za sprawą licznych podstołecznych parcelacji, odbywających się w latach dwudziestych i trzydziestych właśnie pod szyldem „miasta-ogrodu” ${ }^{15}$. Największym rozgłosem wśród nich cieszyła się niewątpliwie parcelacja Podkowy Leśnej.

\section{Podkowa Leśna}

Impulsem do fundacji „miasta-ogrodu” Podkowa Leśna stała się budowa podmiejskiej elektrycznej linii kolejowej Warszawa-Grodzisk-Żyrardów. Inwestycja realizowana przez Spółkę Akcyjną „Elektryczne Koleje Dojazdowe” (dalej cyt.: EKD) powstałą w 1922 r. w ramach grupy kapitałowej „Siły i Światło” (dalej cyt.: „SiŚ”) wspierana była przez Ministerstwo Komunikacji liczące na ożywienie tych podwarszawskich obszarów ${ }^{16}$. Początkowo trasa kolejki na odcinku Pruszków-Grodzisk wyznaczona została przez atrakcyjne pod kątem zasiedlenia lasy Młochowskie. Jednak ze względu na brak zgody ich właścicielki na podpisanie stosownej umowy linię przesunięto i poprowadzono przez przylegający do nich majątek Podkowa Leśna, wydzielony w 1909 r. z dóbr brwinowskich ${ }^{17}$. Rozmowy z dysponentem tych ziem, Stanisławem Lilpopem, doprowadziły nie tylko do wspomnianej korekty linii EKD, ale również do powołania wiosną 1925 r. spółki pod nazwą „Miasto-Ogród Podkowa Leśna”. Jej naczelnym zadaniem było: „stworzenie na tych terenach osiedla wedle najnowszych, racjonalnych zasad, ujętych w modnej w tych czasach nazwie: miasto-ogród, w odróżnieniu od na ogół na dziko i bezplanowo powstających w ówczesnej Polsce osiedli [...]”18. Do spółki weszli: Lilpop (40\% udziałów), „SiŚ’ (36\%) oraz Bank Związku Spółek Zarobkowych (24\%) ${ }^{19}$. Z trójki udziałowców

${ }^{13}$ Na jej popularyzację wpłynęła też zapewne wizyta samego Howarda w Krakowie w 1912 r. Odczyt dotyczący „miast-ogrodów” wygłoszony podczas wystawy architektury (dodajmy, jako ciekawostkę, w języku esperanto) zgromadził szerokie audytorium oraz znalazł oddźwięk w specjalistycznej prasie, Miasta-Ogrody. 1912, s. 82-83.

14 Więcej na ten temat zob.: Czyżewski A. 2009, s. 129-142. Warto też wspomnieć o osiedlach robotniczych nawiązujących do założeń idei „miasta-ogrodu”, wybudowanych na Górnym Śląsku. Niektóre z nich, takie jak: Knurów, Giszowiec lub Stara Rokitnica w Zabrzu szczegółowo omawia Joanna Sokołowska-Moskwiak (Sokołowska-Moskwiak J. 2011, s. 64-111). Niestety praca ta zawiera też dość rażące błędy dotyczące wydarzeń historycznych, jak chociażby ten mówiący o podziale Śląska podczas trzech rozbiorów Polski, Sokołowska-Moskwiak J. 2011, s. 24.

${ }^{15}$ Czyżewski A. 2001, s. 34-35.

16 Regulski J. 1980, s. 273, 275.

17 Dobra brwinowskie nabył w 1861 r. Stanisław Lilpop (senior), współwłaściciel największej w Warszawie fabryki budowy maszyn. Majątek składał się z czterech folwarków: Brwinowa, Marynina, Kępiny i Wilhelmowa (nazwa tego ostatniego z czasem uległa zmianie na Podkowę Leśną). Jeszcze przed wybuchem pierwszej wojny światowej majątek był sukcesywnie rozprzedawany przez kolejnego właściciela — Stanisława Lilpopa (juniora). Ich atrakcyjność wzrosła wraz z uruchomieniem w 1845 r. Kolei Warszawsko-Wiedeńskiej i wybudowaniem w centrum Brwinowa jej przystanku. Wówczas na całej trasie zaczęły powstawać kolonie letniskowych willi (Wróblewski B. 1995, s. 15-16, 18). Więcej o przybyłej na przełomie XVIII i XIX w. z Grazu, stolicy Styrii, rodzinie Lilpopów, zob.: Wróblewski B. 1995, s. 14-16; Pustuła Z. 1972.

${ }_{18}$ Regulski J. 1980, s. 282.

19 Spółka Akcyjna „SiŚ” powstała w grudniu 1918 r. jako pierwsza w ogóle spółka akcyjna w odrodzonej Polsce, stając się wkrótce jednym z największych przedsiębiorstw w kraju, grupując szereg elektrowni (jako 
wiodącą rolę w przedsięwzięciu odgrywała Spółka „SiŚ”, którą w początkowej, krytycznej fazie koncepcyjno-organizacyjnej reprezentował jeden z jej dyrektorów Janusz Regulski, któremu też zawdzięczamy spisane wspomnienia z tego okresu realizacji projektu. Rozwojem osiedla żywotnie zainteresowane były też EKD (autonomiczna spółka w ramach „SiŚ’), której dyrektor Tadeusz Baniewicz nawiązał ścisłą współpracę z Regulskim i aktywnie włączał się do $\operatorname{prac}^{20}$. Nie jest natomiast w pełni jasne, jakimi motywami kierować się mógł świetnie sytuowany i raczej dobrze zabezpieczony finansowo Lilpop, który, wycofawszy się już wówczas z biznesowej działalności, oddawał się przede wszystkim największej pasji swego życia — myślistwu ${ }^{21}$. Obecna w literaturze interpretacja jakoby: „Zysk, obrót kapitałem, interes wzięły górę nad pragnieniem utrzymania w bliskim sąsiedztwie Warszawy enklawy romantycznych terenów łowieckich i skromnej gospodarki rolniczej” niezupełnie przekonuje ${ }^{22}$.

Wydaje się, iż szukając przyczyn decyzji Lilpopa o parcelacji Podkowy Leśnej, należy wziąć pod uwagę jeszcze inną, nie podnoszoną do tej pory okoliczność, a mianowicie rozpoczęte niemal od powstania drugiej Rzeczypospolitej prace legislacyjne nad reformą rolną. Pierwsza ustawa w tej sprawie, uchwalona w obliczu zagrożenia radzieckiego w połowie lipca 1920 r., wprowadzająca limity posiadanej ziemi (od 60 do 180 ha) oraz odszkodowania za wywłaszczone majątki w wysokości połowy ceny rynkowej, nie doczekała się realizacji. Była bowiem sprzeczna z zapisami Konstytucji marcowej (artykuł 99), gwarantującej wszelką własność. Nie ulegało jednak wątpliwości, iż w niedalekiej przyszłości należało oczekiwać nowego wariantu rozwiązania tego newralgicznego problemu społecznego i gospodarczego. Mając to na uwadze, Lilpop musiał się liczyć z nieuniknioną raczej koniecznością parcelacji znaczącej części swoich dóbr, jako przekraczających pojawiające się we wszystkich dotychczasowych propozycjach limity ziemi przypadające na jedną osobę. Zatem podjęte przez niego w 1922 r. z EKD rozmowy w celu poprowadzenia przez Podkowę Leśną trasy kolejki miały na celu zwiększenie atrakcyjności posiadanej ziemi w obliczu już przewidywanego przymusu jej sprzedaży. Zawiązanie z kolei spółki „Miasto-Ogród Podkowa Leśna” z poważnym partnerem, jakim była już wówczas „SiŚ”, było niejako krokiem wyprzedzającym w obliczu nieprzesądzonego jeszcze do końca kształtu regulacji, które miała wprowadzić ustawa o reformie rolnej (uchwalona ostatecznie w grudniu 1925 r.) $)^{23}$. Dyskutowane warianty ustawowych rozstrzygnięć mogły zapewne wzbudzać lęk i niepewność wśród posiadaczy dużych majątków. Chodziło więc tutaj o uzyskanie gwarancji w kwestii sprzedaży ziemi na satysfakcjonujących Lilpopa warunkach. Wobec spodziewanego nasilenia się ruchów parcelacyjnych (co rzeczywiście nastąpiło po wejściu w życie wspomnianej ustawy) takie działanie należa-

pierwsze nabyła elektrownie w Pruszkowie oraz w Sosnowcu) oraz zakładów przemysłu elektryfikacyjnego. Inwestowała również w sektorze kolejowym, głównie w budowę sieci tramwajowej w Zagłębiu Dąbrowskim oraz w EKD. Bank Związku Spółek Zarobkowych (dalej cyt.: BZSZ) powstał w 1885 r. w Poznaniu. W drugiej RP był najsilniejszym, obok Banku Handlowego w Warszawie SA, bankiem prywatnym, działającym w całym kraju. W okresie wielkiego kryzysu gospodarczego zagrożony upadkiem, utrzymał się dzięki pomocy finansowej państwa, które odtąd stało się jego największym akcjonariuszem.

20 Jak każde z przedsiębiorstw „SiŚ’, EKD była odrębną spółką akcyjną, o własnej osobowości prawnej, władzach statutowych i dyrekcji. Podział akcji był następujący: „SiŚ” — 40\%, BZSZ — 25\%, pozostała część w rękach drobnych akcjonariuszy, Regulski J. 1980, s. 275.

21 Regulski J. 1980, s. 287.

22 Wróblewski B. 1995, s. 17-18, 27.

${ }^{23}$ Wprowadzała ona obowiązkową parcelację m.in. także prywatnych majątków w sytuacji, gdy w posiadaniu jednej osoby znajdował się obszar przekraczający (poza pewnymi określonymi wyjątkami) 180 ha. W okręgach podmiejskich np. wartość ta dla użytków rolnych została obniżona do 60 ha, zaś w województwach wschodnich podwyższona do 300 ha. Do norm tych nie wliczano sadów, dróg, terenów zabudowanych, obszarów leśnych nadających się do samodzielnego gospodarowania o powierzchni ponad 30 ha (w województwach wschodnich powyżej 50 ha), obszarów stawów rybnych o łącznej powierzchni ponad 3 ha, a także innych obszarów wodnych powyżej 20 ha. Dodatkowo ustawa przewidywała zwiększenie obszaru niepodlegającego obowiązkowej parcelacji z uwagi np. na intensywną produkcję rolną, uprzemysłowienie lub wyspecjalizowanie w hodowli, Ustawa. 1925. 
łoby uznać za jak najbardziej racjonalne. Ubiegające konkurencję wejście „na rynek” z dobrze przygotowaną ofertą handlową zwiększało szanse całego przedsięwzięcia ${ }^{24}$.

Zasady parcelacji i sprzedaży działek uregulowano w odrębnym akcie notarialnym zawartym w kwietniu 1925 r. pomiędzy właścicielem Podkowy Leśnej a pozostałymi przedstawicielami spółki „Miasto-Ogród Podkowa Leśna”. Wedle jego zapisów rozprzedażą obszaru miała zająć się ta ostatnia, gwarantując jednocześnie Lilpopowi cenę 30 gr za m². Łączna kwota z tytułu tej transakcji została oszacowana na ok. 940 tysięcy zł. Spółka obligowała się spłacić ją byłemu właścicielowi w ratach w ciągu dwóch lat, tj. do kwietnia 1927 r., niezależnie od tego, czy uda się jej sprzedać całość terenu ${ }^{25}$. Tak sformułowane regulacje nie wytrzymały jednak, jak można sądzić, konfrontacji z realiami. W grudniu 1927 r. przystąpiono bowiem do likwidacji spółki. Obszar przeznaczony do parcelacji został podzielony pomiędzy trzech byłych udziałowców. Lilpop zatrzymał 40\% powierzchni, a pozostałe $60 \%$ sprzedał „SiŚ” oraz BZSZ w proporcjach odpowiadających ich pierwotnym udziałom ${ }^{26}$.

W latach 1925-1927, a więc za czasów działalności spółki, głównymi sprawami organizacyjno-porządkowymi całości przedsięwzięcia zajmował się jej zarząd (występujący pod nazwą Zarząd Dóbr Podkowa Leśna) ${ }^{27}$. Wypracował on następujący model podziału zadań: 1) bieżące sprawy związane z powstawaniem i funkcjonowaniem osiedla scedowano na powołaną specjalnie administrację, przeznaczając na jej biura dawne zabudowania folwarczne, 2) sprzedaż działek powierzono prywatnej agencji, nad którą zachowano sobie prawo nadzoru, 3) zawieranie umów hipotecznych pozostawiono w wyłącznej gestii zarządu ${ }^{28}$. Po rozwiązaniu spółki schemat uległ pewnym zmianom. Przede wszystkim umowy kupna-sprzedaży z oferentami zawierali już odrębnie poszczególni właściciele gruntów. Utrzymano jednak Zarząd Dóbr, który nadzorował dalsze prace związane z powstawaniem osiedla i w którym do czasu swojej tragicznej śmierci (listopad 1930 r.) udział brał również sam St. Lilpop ${ }^{29}$.

Pod przyszłe „miasto-ogród” przeznaczono 518 morgów (czyli 292 ha) z majątku Podkowa Leśna ${ }^{30}$. Topografia terenu była dość zróżnicowana, stanowiły go bowiem zarówno grunty orne oraz pastwiska byłego folwarku, jak i przylegające doń lasy, od ukształtowania których miejscowość ta przyjęła swą ostateczną nazwę ${ }^{31}$. Dość rozległy, niezalesiony środek, otaczały od wschodniej i południowo-zachodniej strony zwarte kompleksy leśne. W szczegółowym planie osiedla całość obszaru podzielono na jedenaście mini dzielnic (oznaczonych literami od A do K), w których wyodrębniono łącznie 1189 działek o zróżnicowanej wielko-

${ }^{24}$ Tezę tę potwierdzają słowa, które miał wypowiedzieć Lilpop do swojej córki i zięcia już po podjęciu decyzji o parcelacji: „Daję wam tylko 35 hektarów [...] abyście nigdy nie mieli kłopotów z reformą rolną.”, cyt. za: Wróblewski B. 1995, s. 40.

${ }^{25}$ Wróblewski B. 1995, s. 40-41.

26 Za sprzedaną wówczas część Lilpop otrzymał odpowiednio 217 tysięcy zł i 145 tysięcy zł. Ceny działek w końcówce lat dwudziestych wahały się od 1 zł do 4 zł za m², a w drugiej połowie lat trzydziestych — od 3 zł do 10 zł, Wróblewski B. 1995, s. 43, 80.

27 Siedziba nowo utworzonej spółki „Miasto-Ogród Podkowa Leśna” mieściła się na szóstym piętrze gmachu „SiŚ” znajdującym się na ulicy Marszałkowskiej 94 w Warszawie, Regulski J. 1980, s. 285.

${ }^{28}$ Regulski J. 1980, s. 286.

29 Wróblewski B. 1995, s. 44, 55.

30 OAPL, ZATPMOPL, sygn. 13, s. 3. Powierzchnia majątku wynosiła 404 ha. Jeszcze przed powstaniem „miasta-ogrodu” wydzielono z niego z przeznaczeniem na parcelacje dwa zawarte kompleksy o nazwie hipotecznej Brwinów Wille oraz Brwinów Borki o łącznej powierzchni 87 ha, oraz obszar o powierzchni 35 ha. Ten ostatni Lilpop zachował dla siebie i swojej rodziny — córki Anny i jej męża (Jarosława Iwaszkiewicza). Wkrótce wybudowano tam nową rodzinną willę, a teren nazwano Stawiskiem, Wróblewski B. 1995, s. 30, 40.

31 Regulski J. 1980, s. 281. W latach siedemdziesiątych XIX w. na skraju tego lasu powstała osada drewnianych domków letniskowych o nazwie Stanisławów (zniszczone podczas pierwszej wojny światowej), Wróblewski B. 1995, s. 16-17. 


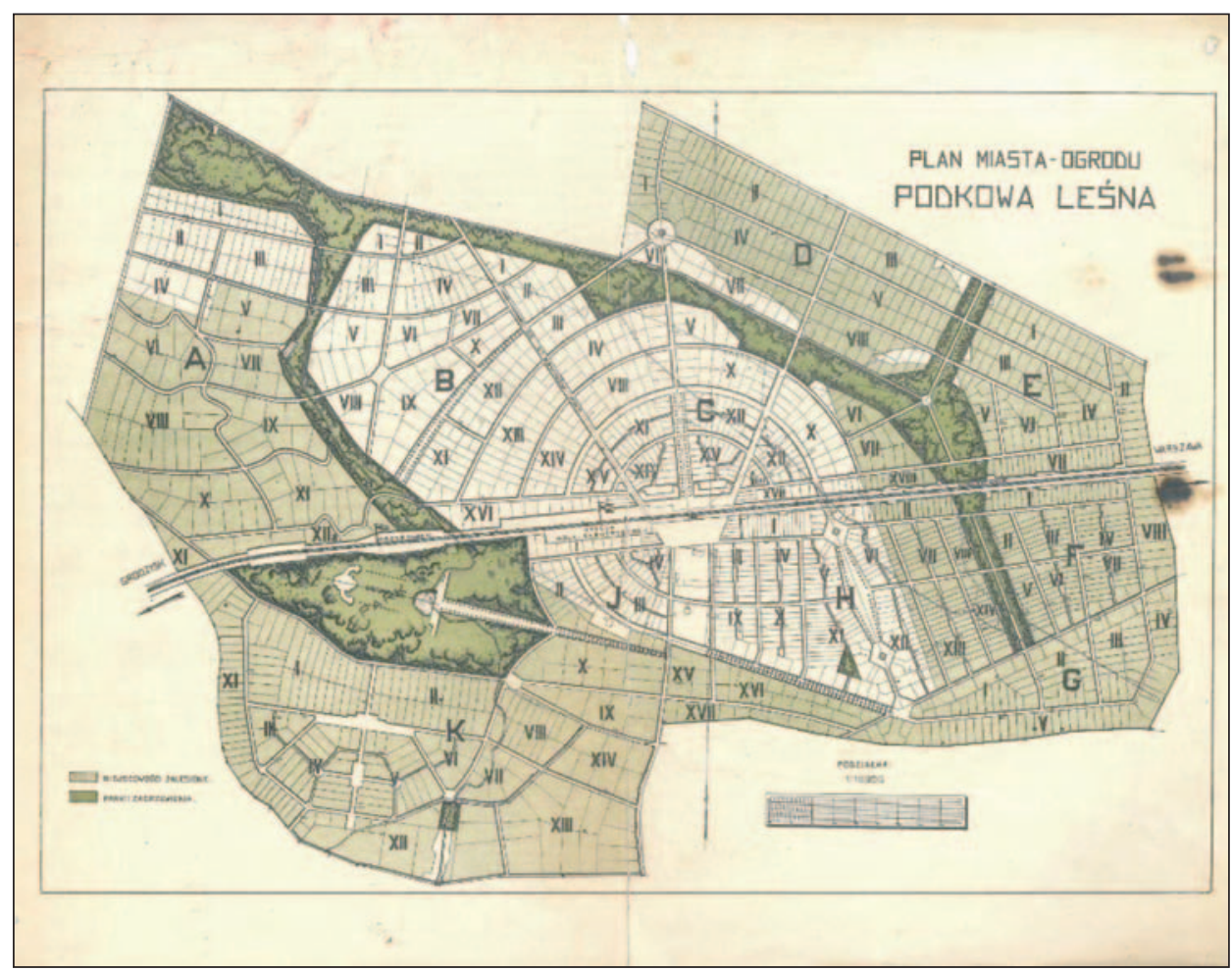

Ryc. 1. Plan Miasta-Ogrodu Podkowa Leśna (źródło: materiały archiwalne Towarzystwa Przyjaciół Miasta Ogrodu Podkowa Leśna, https://www.archiwa.gov.pl/pl/aktualnosci/4877, dostęp 04.05.2020)

Fig. 1. A plan of the garden city Podkowa Leśna (from the archive of the Association of the Friends of the Garden City Podkowa Leśna, https://www.archiwa.gov.pl/pl/aktualnosci/4877, accessed 04.05.2020)

ści (od 1000 do $\left.6000 \mathrm{~m}^{2}\right)^{32}$. W ścisłym centrum, wyznaczonym przez przystanek kolejowy EKD (otwarta w grudniu 1927 r. linia dzieliła miejscowość na dwie zasadnicze części — północną i południową), pozostawiono fragment terenu wyłączony spod parcelacji, z przeznaczeniem, jak się przypuszcza, pod budynki użyteczności publicznej ${ }^{33}$. Niedaleko na południowy zachód od niego zaprojektowano kilkuhektarowy park, a w nim, nad stawem obszerny dom sportowy, place do gier, korty tenisowe i aleje o elipsoidalnym kształcie. Osiedle zaplanowane jako podmiejska miejscowość letniskowo-mieszkaniowa nie miało naturalnych granic, co w przyszłości stanowić mogło potencjalne zagrożenie dla utrzymania jego koncepcyjnej spójności ${ }^{34}$.

32 Plan autorstwa Antoniego Jawornickiego nie zachował się w oryginale (znany jest jedynie z ulotki reklamowej z 1927 r.). Liczba działek przeznaczonych na parcelację zmieniała się. Początkowo zaplanowano ich 1779, w roku 1927 nowy plan geodezyjny zredukował ich liczbę do 1079, zaś korekta z 1934 r. powiększyła do 1189 (Wróblewski B. 1995, s. 50-51). Informacje o wielkości działek są jednak dość niejednoznaczne. Oprócz przytoczonych wyżej przedziałów powierzchni znajduje się także wzmianki o parcelach znacznie je przekraczających — od 8 tysięcy do nawet blisko 20 tysięcy m² (por.: Wróblewski B. 1995, s. 41).

33 Wróblewski B. 1995, s. 36, 50.

34 Wróblewski B. 1995, s. 50-51. 
5 lipca 1926 r. (a więc z górą rok od zawiązania spółki „Miasto-Ogród Podkowa Leśna”) uzyskano decyzją Okręgowego Urzędu Ziemskiego w Warszawie zgodę na parcelację trybem parcelacji letniskowej ${ }^{35}$. Dopiero od tego momentu można było formalnie przystąpić do sprzedaży gruntów. Pierwsze transakcje zawarto jeszcze w tym samym miesiącu. Kupującymi w tej „transzy” były osoby ze ścisłego kręgu kierownictwa „SiŚ” bądź też ich krewni ${ }^{36}$. Regularna sprzedaż rozpoczęła się natomiast z końcem tego roku. Prowadziło ją biuro inżyniera Mieczysława Szydłowskiego, mieszczące się w Warszawie na ulicy Pięknej 44. Wedle sprawozdań Spółki „SiŚ’ akcja cieszyła się dużym zainteresowaniem. Potwierdzają to także dane liczbowe. W ciągu roku sprzedano prawie jedną trzecią działek, a niektórzy zaczęli już budowę domów. Światowy kryzys gospodarczy spowolnił to tempo. Niemniej do grudnia 1932 r. (w którym zanotowano zupełny zastój) wykupiono ok. 69\% ogólnej powierzchni (są to ostatnie dane podawane w literaturze odnośnie do tego parametru). Od 1934 r. sprzedaż odbywała się już w siedzibie „SiŚ ” na ulicy Marszałkowskiej ${ }^{37}$. Wraz z nabyciem pierwszych parcel przez prywatne osoby ruszyła fala budowy willi i pensjonatów. Największy jej impet przypadł na pierwsze, przedkryzysowe jeszcze lata. Do 1930 r. zdołano bowiem postawić 98 willi. W następnych pięciu latach przybyło ich już tylko 42. W sumie do wybuchu drugiej wojny światowej wybudowano 205 obiektów, w tym trzy pensjonaty ${ }^{38}$. Szacuje się, że na stałe bądź czasowo Podkowę Leśną zamieszkiwało pod koniec omawianego okresu ok. 1750 osób.

Z zaplanowanych inwestycji infrastrukturalnych zrealizowanych do czasu rozwiązania spółki, nie licząc doprowadzenia linii kolejowej EKD w grudniu 1927 r. (było to znacznie szersze, wykraczające poza Podkowę przedsięwzięcie), należy wymienić podłączenie do sieci elektrycznej z pobliskiej Elektrowni Okręgowej w Pruszkowie (co w przypadku wiodącego jej udziałowca, tj. „SiŚ” nie było zadaniem trudnym, a prestiżowo niemal koniecznym), utwardzenie i oświetlenie części ulic (nie znamy jednak szczegółów) oraz urządzenie parku. W tym ostatnim postawiono w 1928 r. pawilon sportowy — dwukondygnacyjny budynek częściowo wydzierżawiany na kawiarnię-restaurację, zbudowano tor saneczkowy oraz korty tenisowe ${ }^{39}$. Nie udało się natomiast wybudować szkoły, dzielnicy handlowej, ani projektowanego w parku

35 Na potrzebę uzyskania tej zgody (warunek konieczny w ramach obowiązującej ustawy o wykonaniu reformy rolnej) przygotowano szczegółowy plan parcelacyjny, którego autorem był Kazimierz Mikułowski, Wróblewski B. 1995, s. 50.

${ }^{36}$ Według autora historii powstania miejscowości był to niejako „interwencyjny zakup” spowodowany nikłym zainteresowaniem „kupców działkami w parcelowanej Podkowie”, konieczny w sytuacji, gdy spółka nie wywiązywała się ze zobowiązań płatniczych wobec Lilpopa (Wróblewski B. 1995, s. 41). Rzeczywiście tę pierwszą, niemalże rodzinną rozprzedaż działek wśród prominentnych członków przedsiębiorstwa (o łącznej powierzchni powyżej 15 ha), można interpretować jako niezbędną, szybką interwencję dla częściowego chociażby ratowania zawartej umowy z pierwotnym właścicielem gruntów. Działanie to jednak wymusiła, moim zdaniem, inna okoliczność. To nie „nikłe zainteresowanie kupców”, ale formalna niemożność rozpoczęcia sprzedaży przed wydaniem zgody na parcelację przez organ administracji rządowej spowodowała skomplikowaną sytuację w Spółce w kontekście jej rozliczeń z Lilpopem. Zawierając z nim umowę w kwietniu 1925 r. nie wiedziano jeszcze, jak będzie wyglądał w szczegółach tryb parcelacji, zapisany w uchwalonej kilka miesięcy później ustawie. Przewidziane w niej proceduralne etapy (wraz z wymogami dostarczania odpowiedniej dokumentacji i terminami rozpatrywania spraw) z pewnością wydłużyły przewidywany wstępnie przez udziałowców spółki czas tej fazy przedsięwzięcia, komplikując jednocześnie mocno sprawę rozliczeń z Lilpopem. Być może w ogóle od początku nie oszacowano właściwie czasu potrzebnego do przygotowania terenu pod sprzedaż pod kątem prawnym, logistycznym, organizacyjnym.

37 Wróblewski B. 1995, s. 42, 55-56, 64.

38 Wróblewski B. 1995, s. 55, 81. Informacja o 205 obiektach w Podkowie Leśnej pochodzi z oficjalnego wykazu sporządzonego w 1941 r. Można jednak przyjąć, iż oddaje ona także stan rzeczy na czas tuż przed wrześniem 1939 r. (w trakcie wojny bowiem nikt raczej nie stawiał nowych domów).

${ }^{39} \mathrm{~W}$ parterowej części pawilonu mieściły się sale przeznaczone do ping-ponga oraz prysznice, na piętrze zaś znajdowała się duża sala wykończona lustrami oraz boczne pokoje do gry w brydża, Michałowska K. 2002, s. 21. 
basenu kąpielowego ${ }^{40}$. Ze sporymi trudnościami powstawał poświęcony w 1934 r. kościół, wykańczany i wyposażany w kolejnych latach. Do jego wzniesienia potrzebne okazały się nie tylko inicjatywa i finansowe nakłady miejscowej społeczności (a w większości stanowiły ją dobrze sytuowane osoby), ale także sponsoring i hojność wielu przedsiębiorstw i instytucji ${ }^{41}$.

Prawdopodobnie już pod koniec lat dwudziestych mieszkańcy Podkowy Leśnej, zgodnie z przewidywaniami Howarda o pozytywnym wpływie atmosfery „miasta-ogrodu” na wyzwalanie społecznej energii, założyli stowarzyszenie. W marcu 1930 r. Towarzystwo Miłośników Miasta-Ogrodu Podkowa Leśna decyzją wojewody warszawskiego zostało zalegalizowane i wpisane do rejestru stowarzyszeń. Z niewiadomych jednak powodów faktyczną działalność podjęło dopiero dwa lata później, gdy odbyło się pierwsze Walne Zgromadzenie, na które przybyło trzydziestu trzech członków ${ }^{42}$. W statucie jako cel stowarzyszenia zapisano: a) uporządkowanie hipoteki poszczególnych parceli nabytych przez stowarzyszonych, b) urządzenie wzorowego osiedla, c) utrzymanie go na wysokim poziomie pod względem administracyjno-gospodarczym, zdrowotnym i ogólnokulturalnym, oraz d) utrzymanie go w polskich i chrześcijańskich rękach ${ }^{43}$. Dla osiągnięcia powyższych celów wyznaczono sobie m.in. podjęcie starań o udogodnienia komunikacyjne (telefoniczne, telegraficzne, pocztowe), o inwestycje (takie jak oświetlenie, kanalizacja, wodociągi), o założenie oraz utrzymywanie straży ogniowej, szpitali, czytelni, bibliotek, szkół, sklepów, parków, ogrodów oraz o urządzanie, ulepszenie i utrzymywanie w należytym porządku chodników i ulic. W ramach stowarzyszenia powołano kilka sekcji: budowlano-sanitarną, ochrony przyrody i sportową, budowy kościoła, oświetlenia, ustalenia nazw ulic i nieco później powstałą bezpieczeństwa ${ }^{44}$. Analiza składu dwóch pierwszych Zarządów oraz Komisji Rewizyjnych, w których dominowały osoby związane z „SiŚ” i BZSZ, daje podstawę do przyjęcia hipotezy, iż powołanie stowarzyszenia było bardziej inicjatywą inspirowaną przez Zarząd Dóbr (czyli parcelantów), który w ten sposób starał się przesunąć ciężar administrowania osiedla na „barki” mieszkańców, niż oddolną akcją, wyrastającą z uświadomionych potrzeb i troski „zwykłych” nabywców działek $^{45}$. Sytuacja zmieniła się jednak w 1935 r., gdy w wyniku nowych wyborów odsunięto od kierowniczych funkcji osoby związane z poprzednimi Zarządami Towarzystwa. Organizacja wyznaczyła sobie wówczas nieco inny (skromniejszy) zakres i model działania, skupiając się przede wszystkim na ochronie przed parcelacją terenów przeznaczonych do użytku publicznego oraz na egzekwowaniu zobowiązań dotyczących estetyki i warunków zdrowotno-sanitarnych osiedla ${ }^{46}$. Nie zrezygnowała też ze starań o zapewnienie sobie wpływu na dalszą zabudowę miejscowości. W tym również roku zainaugurowano wydawanie Biuletynu Towarzystwa ${ }^{47}$.

40 Wróblewski B. 1995, s. 56-57.

41 Wróblewski B. 1995.

${ }^{42}$ Niestety w literaturze nie jest podawana ogólna liczba członków w momencie powstania stowarzyszenia.

${ }^{43}$ W 1933 r. wprowadzono pewne modyfikacje do tekstu Statutu. Zmieniono np. nazwę stowarzyszenia na Towarzystwo Przyjaciół Miasta-Ogrodu Podkowa Leśna oraz zniesiono opisane w podpunkcie „d” dyskryminacyjne ograniczenia, Wróblewski B. 1995, s. 71.

${ }^{44}$ Wróblewski B. 1995, s. 69-70.

45 Wróblewski B. 1995, s. 70. Dodajmy, iż pierwszym prezesem Stowarzyszenia został zamieszkały w Podkowie Leśnej ówczesny minister komunikacji — Alfons Kühn.

${ }^{46} \mathrm{~W}$ tekstach umów przyrzeczenia kupna wpisywano tzw. zastrzeżenia hipoteczne opracowane przez Zarząd Dóbr, nakładające na nowych właścicieli pewne obowiązki i ograniczenia, odnoszące się np. do zakazu podziału działek, wycinki drzew (poza konieczną do przygotowania placu budowy i ogródka), charakteru zabudowy lub usytuowania urządzeń sanitarnych, OAPL, ZATPMOPL, sygn. 13, s. 10-12; Regulski J. 1980, s. 286; Wróblewski B. 1995, s. 61-62.

47 Wróblewski B. 1995, s. 75-77, 93. 


\section{Kolonia Letnia Żarki}

Analiza okoliczności powstania Kolonii Letniej Żarki skłania do wniosku, iż podobnie jak w przypadku Podkowy Leśnej, tak i tu reforma rolna stała się główną przyczyną podjęcia decyzji o parcelacji. Karol Raczyński (wnuk po kądzieli wieszcza Zygmunta Krasińskiego i przyrodni brat Rogera oraz Edwarda Raczyńskich), dziedzic rozległego majątku Złoty Potok, położonego w Jurze Krakowsko-Częstochowskiej, oraz dwóch całkiem też sporych posiadłości na Lubelszczyźnie musiał się liczyć, tak jak i Lilpop, z koniecznością pomniejszenia swoich włości $^{48}$. Nie czekając na ostateczne rozstrzygnięcia w tej sprawie (tj. administracyjne decyzje określające wielkości powierzchni gruntów ornych przeznaczonych na cele reformy), przystąpił on do dobrowolnej parcelacji przeszło dwustuhektarowego obszaru z dóbr żareckich z intencją utworzenia tam nowej mieszkalnej osady wpisanej w koncepcję „miasta-ogrodu”49. Prawdopodobnie miał to być sposób na uniknięcie narzuconych odgórnie parcelacji (których już wcześniej doświadczył) oraz, co wydaje się jeszcze silniejszą motywacją, na podreperowanie własnego budżetu ${ }^{50}$. Z różnych bowiem powodów, w tym także $\mathrm{z}$ uwagi na stale rosnące fiskalne obciążenie ziemiaństwa, sytuacja finansowa Stefanii i Karola Raczyńskich była stale napięta. Komplikowały ją również długi zaciągnięte na zakup przylegających do Złotego Potoku (odziedziczonego po Krasińskich) dóbr żareckich. Tę posiadłość, niegdyś sławną (za sprawą pioniera polskiej przedsiębiorczości Piotra Steinkellera), ale wówczas mocno już podupadłą, okrojoną i zadłużoną, nabył Raczyński w 1916 r. Miała ona jednak niebagatelny atut, zapewniający duży potencjał rozwoju, prawdopodobnie dostrzeżony przez hrabiego świetnie zorientowanego w technicznych zagadnieniach. Przez żareckie włości przechodziła bowiem linia Kolei Warszawsko-Wiedeńskiej, na której rok wcześniej, w odległości kilkunastu kilometrów od miasteczka Żarki otworzono przystanek o takiej samej nazwie. Pasjonat i propagator nowoczesnych środków lokomocji nie mógł takiej okazji przegapić. Kto wie zatem, czy już w momencie zakupu, obserwując przedwojenny (tj. sprzed pierwszej wojny światowej) rozwój podwarszawskich osad letniskowych położonych wzdłuż wspomnianej arterii komunikacyjnej, a wpisujących się w pewien szerszy ogólnoeuropejski trend związany z upowszechnieniem kolei, Raczyński nie myślał o podobnym zagospodarowaniu tych terenów. Do realizacji pomysłu, już pod szyldem „miasta-ogrodu”, przystąpił zachęcony, jak można domniemywać, początkowym sukcesem „Podkowy Leśnej”. Tym bardziej, iż szczegółową wiedzę odnośnie do planistycznej i organizacyjnej strony tegoż przedsięwzięcia mógł czerpać niejako „z pierwszej ręki”. Zarówno bowiem Lilpop, jak i Regulski, byli członkami elitarnego Automobilklubu Polski, którego czołową postacią pozostawał przez cały niemal okres drugiej Rzeczypospolitej właśnie Karol Raczyński (sprawując godność prezesa, względnie jego zastępcy). Zwłaszcza z młodszym Regulskim połączyły go więzy trwałej przyjaźni ${ }^{51}$.

${ }^{48}$ Postać Karola Raczyńskiego, w przeciwieństwie do jego przyrodnich braci, nie doczekała się jeszcze pełnego opracowania (ukazał się jedynie biogram zamieszczony w Polskim Slowniku Biograficznym — Roszkowski W. 1986, s. 644). Karol Raczyński posiadał następujące majątki na terenie drugiej RP: Janów vel Złoty Potok znajdujący się na terenie woj. kieleckiego (składający się z trzech jednostek hipotecznych: Janów, Lusławice i Żarki) oraz Kraśniczyn-Czemierniki leżący w woj. lubelskim. Ich łączna powierzchnia wynosiła (dane na lata 1929 i 1930) 13237 ha (z tego na użytki rolne przypadało 1476 ha w woj. kieleckim i 1776 ha w woj. lubelskim). W deklaracji z 1927 r. wymieniane były również dobra Dąbrowno w powiecie będzińskim, AP Kielce, OUZ, sygn. 4317, s. 20, 285-298, 318-350.

${ }^{49}$ Wedle ostatecznych ustaleń Raczyński zobligowany był do „oddania” na cele reformy 243 ha z dóbr położonych w woj. kieleckim oraz 1030 ha z dóbr znajdujących się w woj. lubelskim.

50 Już wcześniej, w 1927 r. Karol Raczyński na skutek wejścia w życie ustawy o wykonaniu reformy rolnej zmuszony był do rozparcelowania 50 ha z majątku Janów, Rozporządzenie. 1927, s. 11.

${ }^{51}$ Regulski J. 1980, s. 326-327, 337-338. Kosztowna automobilowa pasja też z pewnością nadwyrężała finanse Raczyńskiego. 


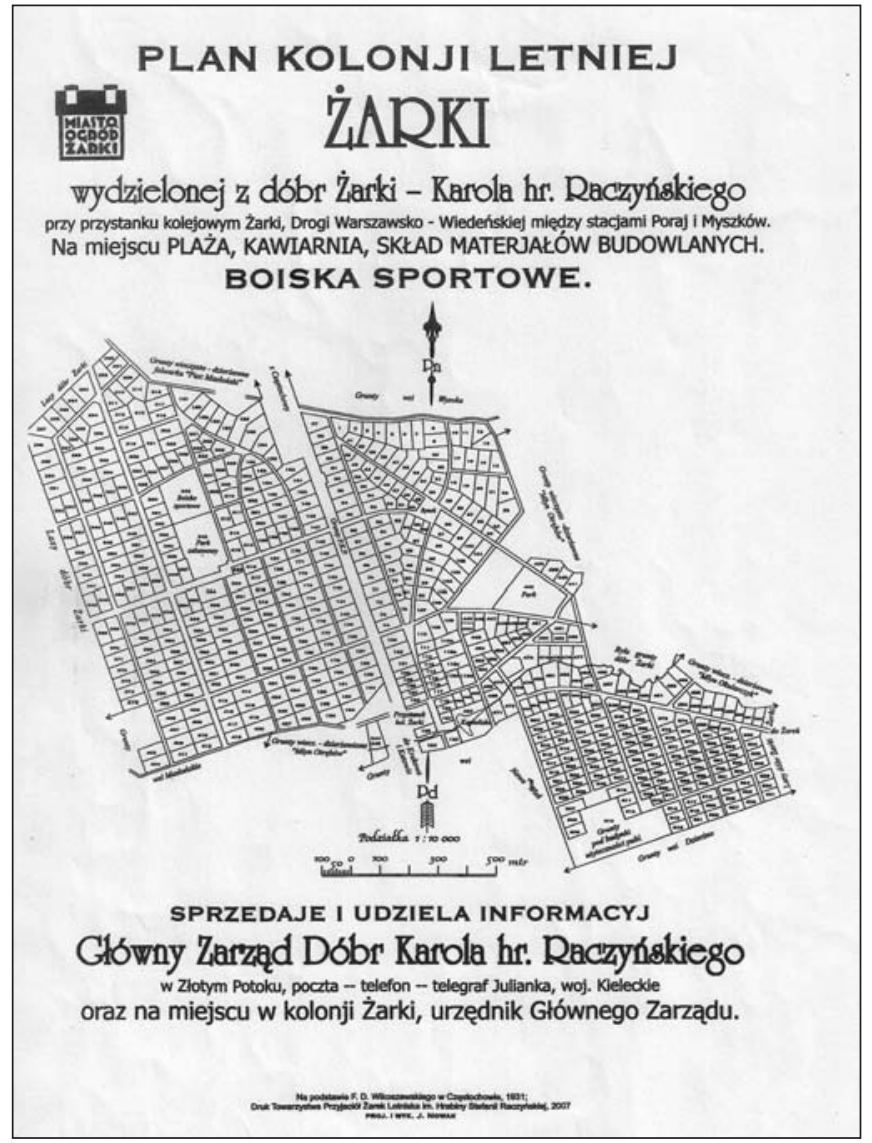

Ryc. 2. Folder reklamowy Kolonii Letniej Żarki

(źródło: zbiory Towarzystwa Przyjaciół Żarek Letniska im. Hrabiny Stefanii Raczyńskiej)

Fig. 2. An advertising brochure for Kolonia Letnia Żarki (from the archive of the Association of the Friends of Żarki Letnisko)

Nadzór nad organizacyjnym wymiarem spraw związanych z projektem sprawował Główny Zarząd Dóbr i Interesów hr. Karola Raczyńskiego, mieszczący się w Złotym Potoku. Wydelegowani do tego zadania urzędnicy, wyposażeni w niezbędne notarialne upoważnienia, tworzyli potrzebną dokumentację, przedkładali do organów administracji stosowne podania wraz z załącznikami, wykazy nabywców działek, korespondowali z potencjalnymi oferentami, zawierali umowy przedwstępne kupna-sprzedaży i akty notarialne ${ }^{52}$. Wyznaczona została też specjalna osoba (leśniczy Jan Brylski) odpowiedzialna na miejscu za sprawy Kolonii. W 1932 r. w „Mieście-Ogrodzie Żarki” po zrealizowaniu przez hrabiowską parę pierwszych budowlanych inwestycji otwarto biuro parcelacyjne.

Od strony formalno-urzędniczej Kolonia powstawała niejako w dwóch fazach. Po uzyskaniu od wojewody pozwolenia na przekształcenie terenów leśnych na użytki rolne, warunkują-

52 W przypadku pierwszej parcelacji pełnomocnictwo takie otrzymał Jan Feliks Jurkowski, a w drugiej Feliks Szczęsny Libiszowski. Od 1937 r. sprawy majątkowe przejął syn Karola, Roger. 
cego w ogóle możliwość realizacji całego przedsięwzięcia, Zarząd wystąpił we wrześniu 1928 r. do Okręgowego Urzędu Ziemskiego w Kielcach (za pośrednictwem Powiatowego Urzędu Ziemskiego w Zawierciu) z wnioskiem o zgodę na parcelację początkowo 100 ha $6094 \mathrm{~m}^{2} 53$. Po przeszło dwóch latach zdecydowano się na powiększeniu obszaru miejscowości o dodatkowe 124 ha $3897 \mathrm{~m}^{2}{ }^{54}$.

Pod przyszłe „miasto-ogród” przeznaczył Raczyński łącznie 225 ha (a więc tylko 65 ha mniej niż Lilpop) najbardziej wysuniętej w kierunku południowym części żareckich dóbr zlokalizowanych po obu stronach wspomnianego wyżej przystanku kolejowego Żarki. Teren miał w przeważającej mierze leśny charakter, a porastał go względnie młody (20-60 lat w zależności od miejsca) sosnowy las. Na południowo-wschodnich obrzeżach przepływała niewielka rzeczka Czarka, nad którą ulokowane były nieliczne zabudowania dawnej wieczysto-dzierżawnej osady młyńskiej, sięgającej swymi początkami jeszcze XIX w. W momencie tworzenia „miasta-ogrodu”, w wyniku pożaru młyna nie pełniła już ona swoich pierwotnych funkcji, a jej obszar (za wyjątkiem niewielkiej enklawy) stał się częścią Kolonii Letniej Żarki. Ze wszystkich stron miejscowość otaczały tereny zielone — lasy, względnie łąki i pola sąsiadujących z nią wiejskich przysiółków. Osada planowana była jako miejsce wypoczynkowo-rekreacyjno-uzdrowiskowe. Jej atutami były świeże powietrze, sezonowo wzbogacone o aromatyczne olejki sosnowe, sucha piaszczysta glebie, możliwość bliskiego kontaktu z przyrodą, oraz dogodne połączenie kolejowe z miastami Zagłębia Dąbrowskiego, Częstochową, tudzież Zawierciem.

Pomiar gruntów przeznaczonych do pierwszej parcelacji oraz szczegółowy rysunek projektowanej miejscowości (tzw. pierworys) wykonał mierniczy przysięgły, Zygmunt Bucholc. Niezachowany do dnia dzisiejszego projekt parcelacji sporządził znany międzywojenny architekt, absolwent Politechniki Lwowskiej, prof. arch. Wacław Krzyżanowski ${ }^{55}$. Pierwotny obszar przeznaczony pod przyszłą Kolonię Letnią, usytuowany niemalże symetrycznie po obu stronach biegnących południkowo torów kolejowych, podzielony został na 245 parcel przeznaczonych na sprzedaż ${ }^{56}$. W projekcie przewidziano także działki na budynki użyteczności publicznej (szkołę, kościół, kasyno, elektrownię i inne) oraz wydzielono strefę handlowo-usługową, którą zamykał rynek. Wyznaczono również tereny pod dwa duże parki oraz boisko sportowe. Wśród parcel przeważały przekraczające 3 tysiące $\mathrm{m}^{2}$, a największa liczyła $7867 \mathrm{~m}^{2}$.

Obszar drugiej parcelacji, której dokładne pomiary sporządził mierniczy przysięgły Józef Rodkiewicz, składał się niejako z dwóch działów ziemi. Pierwszy, wynoszący ponad 60 ha, wydłużał znacząco miejscowość w kierunku południowym i wschodnim, nieco rozleglejszy drugi powiększał ją na zachodzie. W nowej części Kolonii z obiektów przeznaczonych do

53 AP Katowice, SPZ, sygn. 1196, s. 79. Chociaż ustawa o wykonaniu reformy rolnej nie uwzględniała dużych obszarów leśnych, o czym wspominałam, to jednak wprowadzone rok później rozporządzenie taką możliwość, będącą każdorazowo przedmiotem administracyjnego rozpatrzenia, pozostawiało (Rozporządzenie. 1926). Zgoda wojewody stwarzała dodatkowo właścicielowi Złotego Potoku szansę zaliczenia tych ziem w poczet nadwyżki, którą musiał oddać na cele reformy. Instrukcja parcelacyjna z grudnia 1927 r., przygotowana przez Ministerstwo Reform Rolnych dla Okręgowych Urzędów Ziemskich, będąca szczegółową wykładnią aktów wykonawczych w tej sprawie, zakładała bowiem: „W wypadku parcelacji leśnej połączonej ze zmianą użytkowania leśnego na rolne - projekt parcelacyjny i dowody pomiarowe winny traktować te grunta jako użytki rolne (grunta orne, łąki)”, AP Kielce, OUZ, sygn. 2286, s. 20 i 114.

54 AP Katowice, SPZ, sygn. 1196, s. 89.

55 Muzeum, Kopiał. 1930-1933, s. 400. Wacław Krzyżanowski (1881-1954) był wykładowcą Państwowej Szkoły Sztuk Zdobniczych i Przemysłu Artystycznego w Krakowie, autorem projektów licznych gmachów użyteczności publicznej, w tym obiektów sakralnych, a także prywatnych rezydencji (m.in. gmachu Izby Skarbowej w Krakowie, Wojewódzkiego Szpitalu Okulistycznego w Krakowie Witkowicach i Gmachu Biblioteki Jagiellońskiej w Krakowie), zob.: http://www.inmemoriam.architektsarp.pl/pokaz/waclaw_krzyzanowski,15184 (dostęp 04.05.2020).

56 ASRM, KW, Żarki 32, dokument 45. 


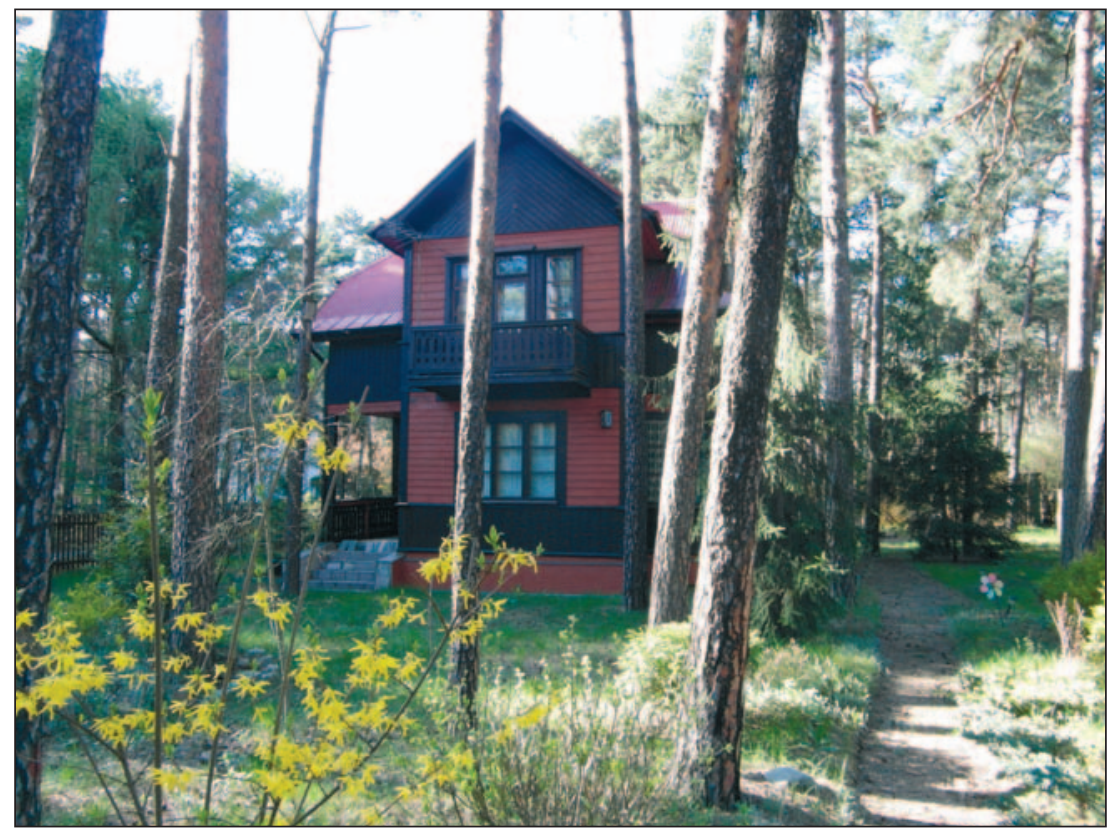

Ryc. 3. Willa w Kolonii Letniej Żarki, stan współczesny (fot. D. Malczewska-Pawelec)

Fig. 3. A villa in Kolonia Letnia Żarki, the present condition (photo by D. Malczewska-Pawelec)

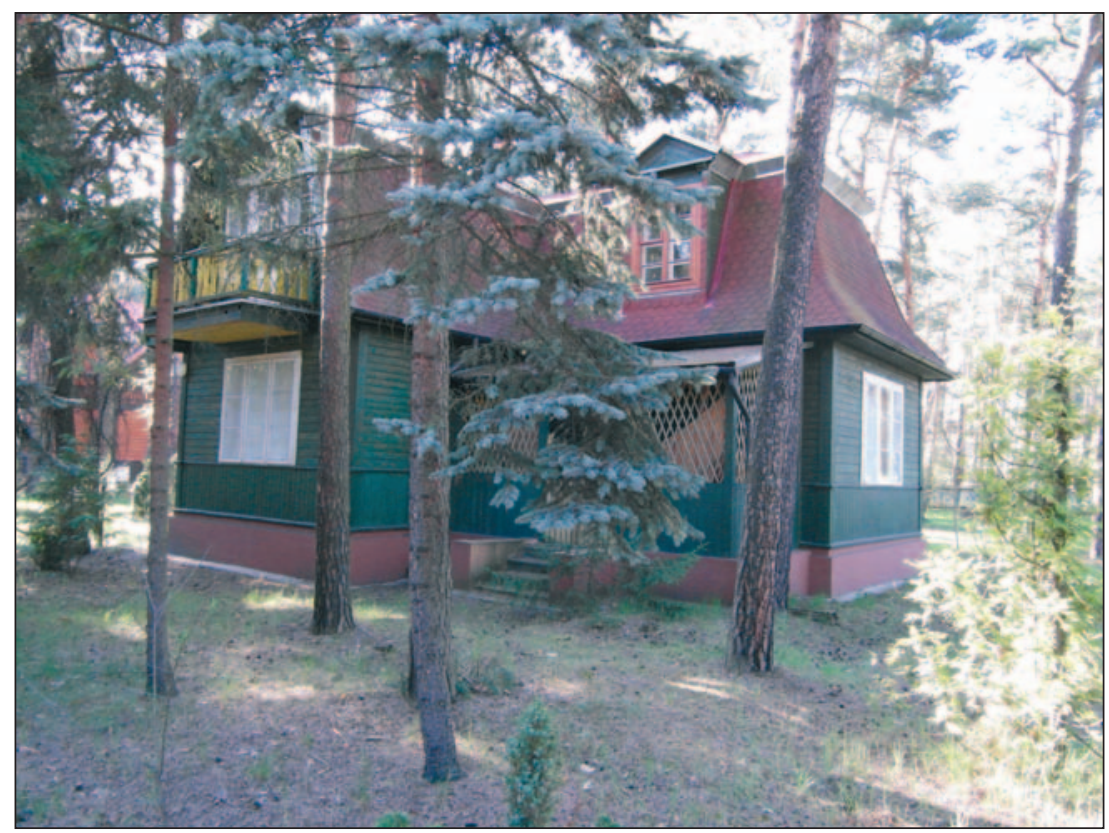

Ryc. 4. Willa w Kolonii Letniej Żarki, stan współczesny (fot. D. Malczewska-Pawelec)

Fig. 4. A villa in Kolonia Letnia Żarki, the present condition (photo by D. Malczewska-Pawelec) 
Ryc. 5. Willa w Kolonii

Letniej Żarki, stan współczesny (fot. D. Malczewska-Pawelec)

Fig. 5. A villa in Kolonia Letnia Żarki, the present condition (photo by D. Malczewska-Pawelec)

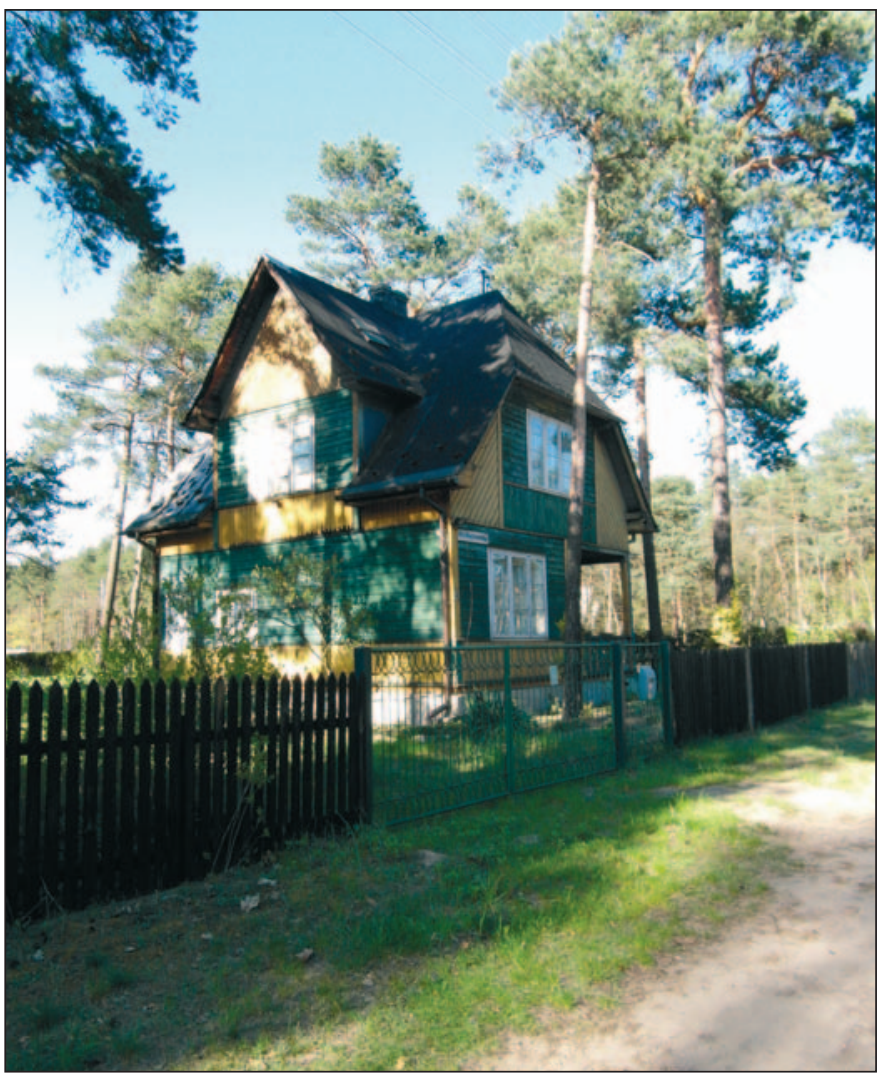

użytku publicznego zaplanowano duży, przeszło dwuhektarowy park oraz kąpielisko. Na sprzedaż wystawiono w sumie 338 działek. W dziale pierwszym zdecydowanie przeważały parcele wielkości od 2 tysięcy do 3 tysięcy $\mathrm{m}^{2}$, w drugim zaś dominowały działki o powierzchni przekraczającej 4 tysiące i 5 tysięcy $\mathrm{m}^{2}$.

W wyniku dołączenia terenów drugiej parcelacji miejscowość zyskała niewątpliwie na atrakcyjności. Zwiększyła się dwukrotnie jej wyjściowa powierzchnia, przez co stawała się ona rozleglejsza i znacznie rozciągnięta na linii północ-południe. Do tego dochodził jeszcze jeden istotny walor w postaci kąpieliska, idealnie wpisującego się w wypoczynkowy charakter Kolonii. Ofertę uzupełniał kolejny (trzeci już) obiekt służący czynnej rekreacji, czyli wspomniany wcześniej park.

Pisząc na adres Zarządu Dóbr w Złotym Potoku można było uzyskać informację o dostępności działek, ich powierzchni oraz cenie. Zainteresowani otrzymywali drogą korespondencyjną planiki miejscowości, celem wstępnego zorientowania się w jej układzie oraz w lokalizacji wolnych jeszcze posesji (każdorazowo zaznaczano na nich te sprzedane i zarezerwowane). W przypadku podjęcia decyzji o kupnie proszono o udanie się na miejsce i przesłanie numeru wybranej działki ${ }^{57}$.

Umowy przedwstępne podpisywano w biurze częstochowskiego notariusza Tadeusza Kossa. Pierwsze zawarto w roku 1929. Parcelę można było nabyć wpłacając całą szacunkową kwotę w momencie zawierania umowy bądź też rozłożyć część tej sumy na raty. Z punktu

${ }^{57}$ Muzeum, Kopiał. 1930-1933, s. 4, 6. 


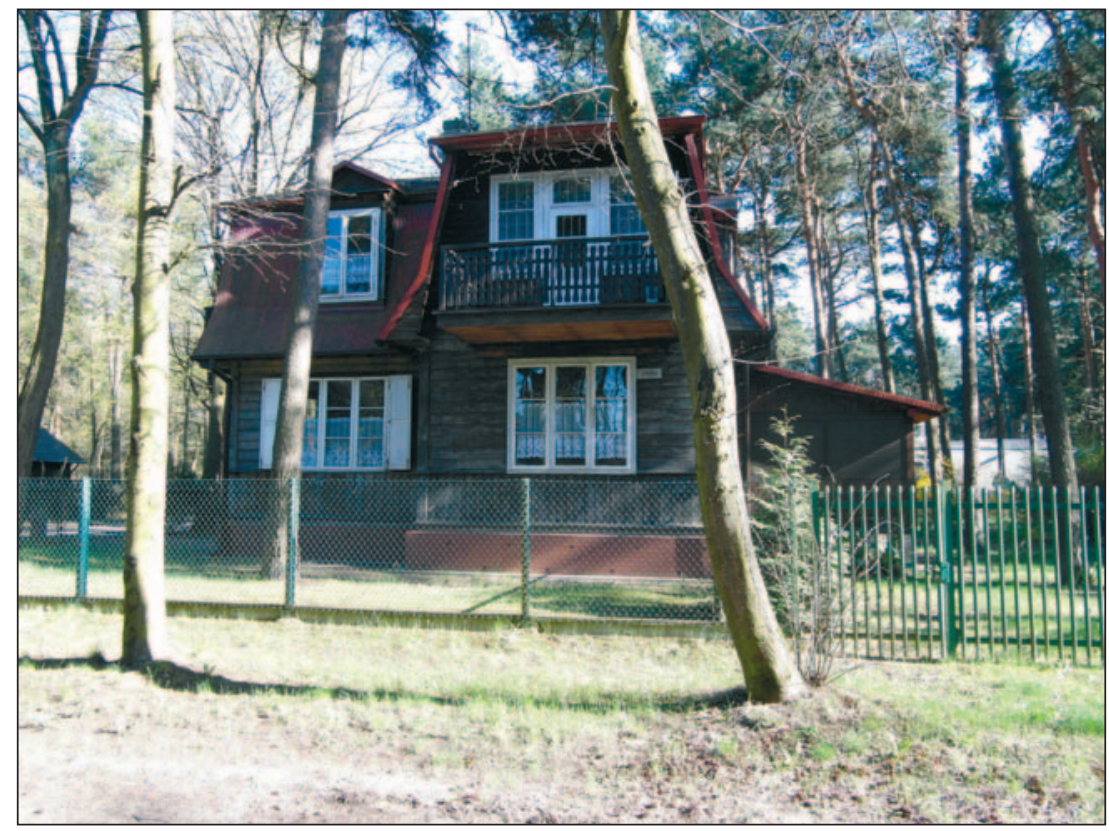

Ryc. 6. Willa w Kolonii Letniej Żarki, stan współczesny (fot. D. Malczewska-Pawelec)

Fig. 6. A villa in Kolonia Letnia Żarki, the present condition (photo by D. Malczewska-Pawelec)

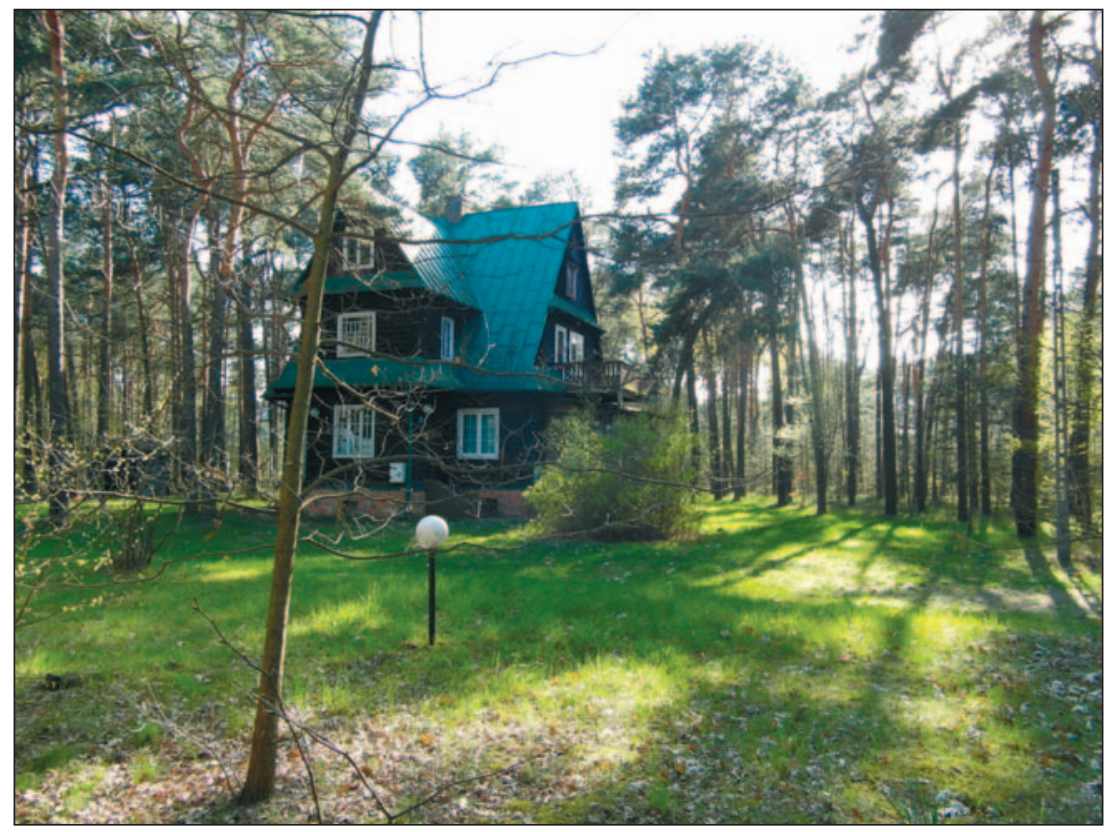

Ryc. 7. Willa w Kolonii Letniej Żarki, stan współczesny (fot. D. Malczewska-Pawelec)

Fig. 7. A villa in Kolonia Letnia Żarki, the present condition (photo by D. Malczewska-Pawelec) 
widzenia interesów hrabiego preferowaną opcją sprzedaży była jednorazowa transakcja gotówkowa. Ci, którzy wybierali taki właśnie sposób rozliczenia, mogli liczyć na dziesięcioprocentowy rabat ${ }^{58}$. Przynajmniej do połowy lat trzydziestych Zarząd Dóbr oferował także, dogodniejszą dla niejednego nabywcy, możliwość ratalnego zakupu działek. Dla wszystkich chętnych, pragnących z takiej propozycji skorzystać, przygotowano jednolite warunki — w momencie zawierania umowy przedwstępnej nabywca wpłacał (co najmniej) połowę należności gotówką, resztę zobowiązywał się uiścić w ciągu dwóch lat w postaci oprocentowanych miesięcznych lub kwartalnych rat ${ }^{59}$. W sumie do wybuchu drugiej wojny światowej sprzedano nieco ponad 200 działek, co stanowi niespełna $36 \%$ wszystkich powstałych w wyniku obu parcelacji ${ }^{60}$.

Od strony technicznej i organizacyjnej nabywcy parcel mogli liczyć na spore udogodnienia. Praktyczni Raczyńscy uruchomili bowiem na miejscu (od sezonu wiosenno-letniego 1932 r.) skład budowlany, w którym można było kupić większość materiałów, niezbędnych do wznoszenia obiektów mieszkalnych (np. cegły, pustaki, słupy, deski, kątowniki, bale, okna, drzwi). Oferowano tam również inne elementy — betonowe słupki do wyznaczania granic działek lub betonowe kręgi, potrzebne do wykonywania studni ${ }^{61}$. Ponadto w okolicy, w Złotym Potoku oraz pobliskiej Juliance, znajdowały się tartaki parowe, w których można było przerabiać drewno pozyskane z wycinki drzew pod przyszłą zabudowę. W tych sprzyjających warunkach w niedługim czasie wzniesiono ok. 30 różnej wielkości domów. Wśród nich znalazły się zarówno okazałe dwukondygnacyjne pensjonaty, jak też nieduże parterowe domki ${ }^{62}$. Liczba mieszkańców Kolonii wraz z osobami podnajmującymi lokale oraz zatrudnianymi do budowy domów w jej szczytowym momencie rozwoju dochodzić mogła do stu osób.

Inaczej niż w przypadku Podkowy Leśnej wybuch światowego kryzysu gospodarczego już na samym starcie spowolnił tempo rozwoju Kolonii Letniej Żarki. Pierwszy obiekt o charakterze publicznym, mający niejako zainicjować „miejscowość”, postawili Raczyńscy w 1932 r. Była to ulokowana w ścisłym centrum kawiarnia serwująca całodzienne wyżywienie. Oprócz usług gastronomicznych zapewniała ona także pewną rozrywkę — grę w bilard oraz bardzo

58 Muzeum, Kopiał. 1930-1933, s. 110.

59 Oprocentowanie wynosiło 1\% miesięcznie. Zarząd wysyłał do nabywcy odpowiednią liczbę blankietów P.K.O. z podanym numerem konta czekowego, na które należało uiszczać płatności.

${ }^{60}$ Umowy notarialne kupna-sprzedaży podpisywano w Sosnowcu, początkowo w kancelarii Antoniego Szczepkowskiego, a następnie jego następy Kazimierza Jewniewicza. Stało się to możliwe dopiero po zatwierdzeniu przez Powiatowy Urząd Ziemski w Zawierciu obu parcelacji wraz z listami nabywców (co nastąpiło w 1933 r.) oraz uiszczeniu przez Raczyńskiego wcale niebagatelnej kwoty w wysokości 12 tysięcy zł z tytułu opłaty za nadzór nad parcelacją. Inaczej niż w przypadku Podkowy Leśnej, w umowach nie wprowadzano żadnych zastrzeżeń hipotecznych w postaci nakładanych na nowych właścicieli obowiązków i obostrzeń. Znalazły się tam natomiast zapisy gwarantujące nabywcom prawo wspólnego użytkowania na wieczne czasy działek przeznaczonych w planie na kościół, kasyno, szkołę, place, ulice, park i boisko.

61 Muzeum, KGR. 1932-1933, s. 29-30.

62 Wedle szacunkowych ustaleń bazujących przede wszystkim na dwóch uzupełniających się źródłach — załączonych do ksiąg wieczystych polisach ubezpieczeniowych od ognia oraz wykazu mieszkańców Kolonii Letniej Żarki sporządzonym przez gminę Żarki — udało się potwierdzić budowę trzydziestu domów (w tej liczbie znalazły się również wystawione przez Raczyńskich willa „Nałęcz” oraz budynek kawiarni, który zawierał część mieszkalną). W tym drugim źródle odnotowano przede wszystkim domy, w których zamieszkiwali czasowo bądź na stałe ich właściciele, względnie lokatorzy. Rzadko w związku z tym figurują w nim domy i domki zamieszkiwane wyłącznie sezonowo. O tych ostatnich informacje pochodzą albo ze wspomnianych ksiąg wieczystych (tu jednak umieszczano polisy przede wszystkim w przypadku obciążenia hipoteki) oraz z relacji ustnych i pisemnych osób związanych z miejscowością, albo (co warto podkreślić) w większości nie będących świadkami narodzin Kolonii (AP Częstochowa, AGŻ, sygn. 248, s. 1-15). W świetle przytoczonych danych szacunkowych wydaje się, iż podana przez ówczesnego proboszcza w Przybynowie (bywającego w Kolonii w niektóre sezonowe niedziele) liczba 70 domów w odniesieniu do lat 1937-1938 jest zawyżona (chyba, iż obejmowała ona także skromne, typowo letnie altanki). Można natomiast przyjąć, iż jakaś liczba domów znajdowała się tuż przed wrześniem 1939 r. w bardziej lub mniej zaawansowanej budowie, Smolarkiewicz W. 1938, s. 20. 


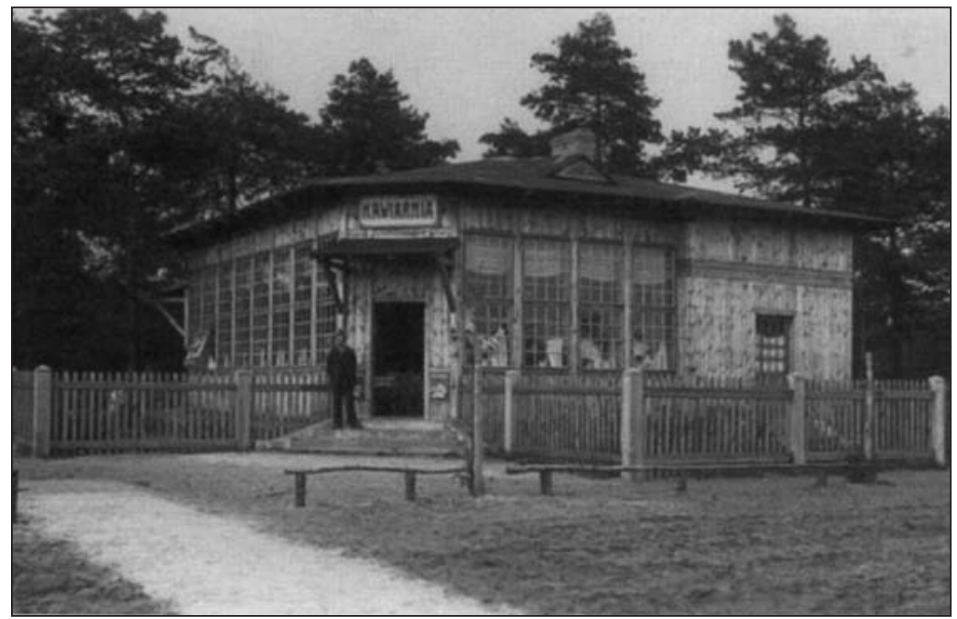

Ryc. 8. Kawiarnia w Kolonii Letniej Żarki (źródło: zbiory

Towarzystwa Przyjaciół Żarek Letniska im. Hrabiny Stefanii Raczyńskiej)

Fig. 8. A cafe in Kolonia Letnia Żarki (from the archive of the Association of the Friends of Żarki Letnisko)

Ryc. 9. Wnętrze kawiarni w Kolonii Letniej Żarki (źródło: zbiory Towarzystwa Przyjaciół Żarek Letniska im. Hrabiny Stefanii Raczyńskiej)

Fig. 9. Inside a cafe in Kolonia Letnia Żarki (from the archive of the Association of the Friends of Żarki Letnisko)
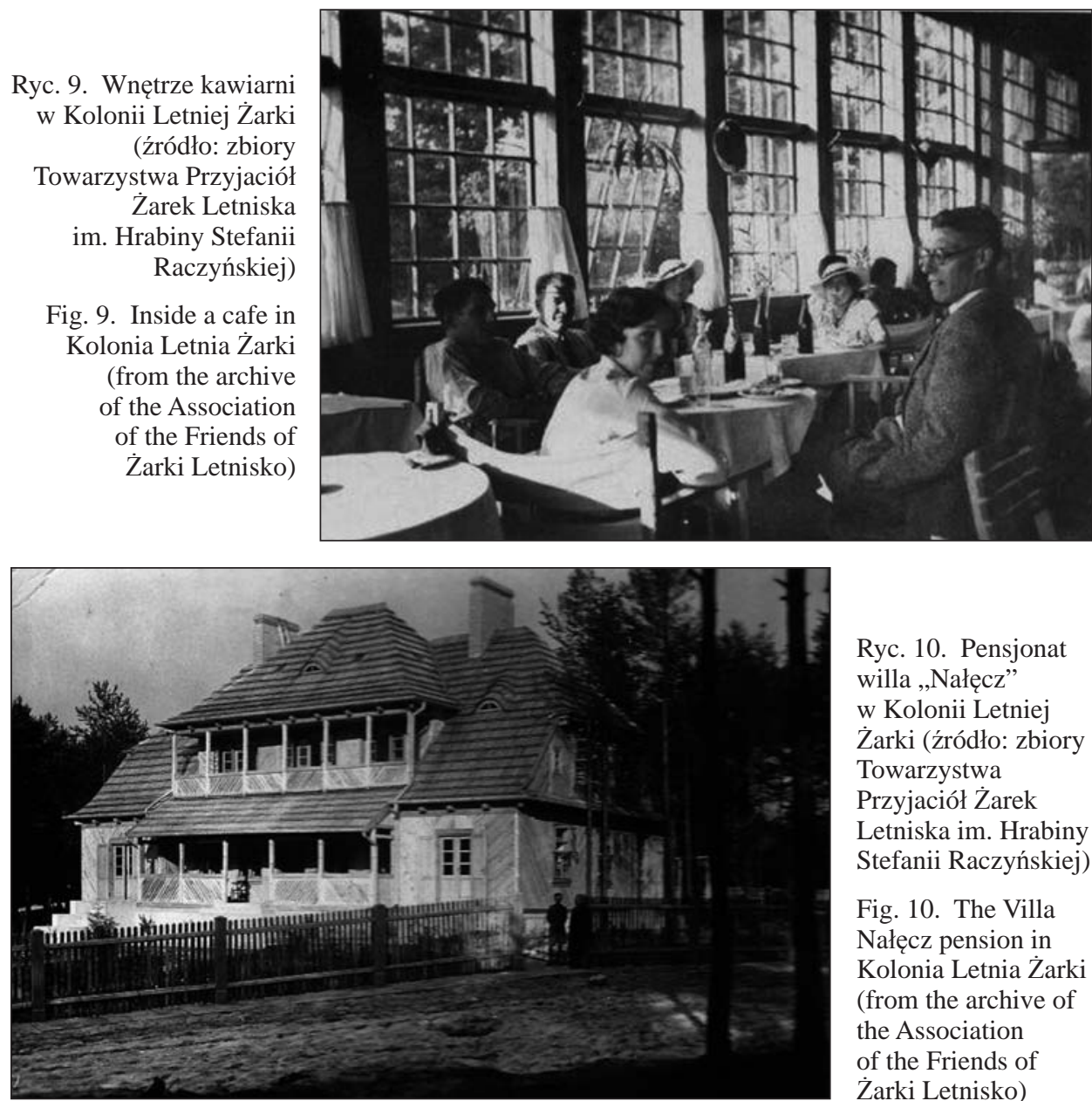

Ryc. 10. Pensjonat willa „Nałęcz” w Kolonii Letniej Żarki (źródło: zbiory Towarzystwa Przyjaciół Żarek Letniska im. Hrabiny Stefanii Raczyńskiej)

Fig. 10. The Villa Nałęcz pension in Kolonia Letnia Żarki (from the archive of the Association of the Friends of Żarki Letnisko) 
popularne dancingi, organizowane w weekendy w sezonie. Lokal po wybudowaniu został oddany w dzierżawę. Budynek był konstrukcją drewnianą, jednopoziomową, dość prostą, choć nie pozbawioną oryginalnych elementów. W miesiącach wiosenno-letnich kubaturę powiększał letni ogródek.

Dwa lata później Raczyński wybudował dość obszerny pensjonat nazwany willą „Nałęcz”. Oprócz dziesięciu pokoi dla gości i części jadalnej, wyposażony został w scenę z zapleczem, korty tenisowe oraz bliżej niedookreślone urządzenia gimnastyczne ${ }^{63}$. Innym poważnym przedsięwzięciem, ufundowanym przez parcelującego, był kościół (ukończony w 1936 r., utrzymany w stylu alpejskim) zaprojektowanego przez studentów Wydziału Architektury Politechniki Warszawskiej, Stanisława Gałęzowskiego oraz Wojciecha Onitzcha ${ }^{64}$.

Z obiektów rekreacyjno-wypoczynkowych wpisanych w plan „Miasta-Ogrodu Żarki” udało się utworzyć leśne kąpielisko (zaopatrzone w budynek rozbieralni), niewątpliwie największą atrakcję osady, oraz usytuowany tuż obok przystanku park, którego ozdobę stanowiła stylowa drewniana altanka, zaprojektowana jako miejsce letnich koncertów ${ }^{65}$.

W drugiej połowie lat trzydziestych Kolonia Letnia Żarki przybrała już zdecydowanie charakter miejscowości rekreacyjno-wypoczynkowej. Całodzienne wyżywienie serwowały trzy obiekty kawiarniano-restauracyjne, ponadto usługi gastronomiczne świadczyły także niektóre z pensjonatów. Niezbędne artykuły spożywcze, ale też i tytoniowe można było nabyć w dwóch sklepach. Z myślą o letnikach czynne były ponadto w sezonie sklepik usytuowany tuż przy stacji kolejowej, oferujący drobne słodycze, owoce i oranżadę oraz kiosk „Ruchu”.

Podobnie jak w Podkowie Leśnej, tak i w Kolonii Letniej Żarki działała grupa osób przejawiających szczególną troskę o dalszy rozwój miejscowości. Skupiła się ona w założonym w 1937 r. „Stowarzyszeniu Właścicieli Nieruchomości w Kolonii Letniej Żarki”“66. Na skutek opieszałości władz swoją formalną działalność rozpoczęła dopiero rok później, to jest z chwilą wydania przez wojewodę kieleckiego postanowienia o rejestracji stowarzyszenia ${ }^{67}$. We wrześniu 1938 r. liczące trzydziestu jeden członków Towarzystwo wybrało swój pierwszy ośmioosobowy Zarząd $^{68}$. Głównym celem zapisanym w statucie była „obrona i popieranie interesów właścicieli nieruchomości i rozwój kolonji letniej Żarki”. Dla jego osiągnięcia rezerwowano sobie m.in. następujące formy działania: zakładanie kas oszczędnościowych (np. pogrzebowej, zasiłkowej), towarzystw dla wzajemnego ubezpieczenia nieruchomości (np. od ognia, bicia szyb

63 Muzeum, Kopiał. 1933-1934, s. 833, 959.

${ }_{64}$ Pieczę nad projektem sprawował inny jeszcze przedstawiciel zasłużonej dla polskiej architektury rodziny Gałęzowskich — inżynier architekt Stefan Gałęzowski. Pomysł powierzenia opracowania tego sakralnego obiektu młodym osobom to zapewne kolejna inicjatywa praktycznych Raczyńskich. Zaproponowane rozwiązanie niosło bowiem ewidentne korzyści dla obu stron. Hrabiostwo bowiem otrzymało (zapewne darmowo) projekt, którego artystyczną jakość i rzetelność gwarantowała warszawska uczelnia oraz dobrze znana im na niwie architektonicznych osiągnięć rodzina Gałęzowskich, z kolei zaś wspomniana dwójka akademików zyskiwała (oprócz ciekawej propozycji tematu pracy dyplomowej) szansę realizacji nakreślonego ich rękoma, pierwszego tak poważnego przedsięwzięcia, będącego w przypadku powodzenia, doskonałą wizytówką ich umiejętności (więcej o S. Gałęzowskim, w: Łoza S. 1954, s. 88; o W. Onitzchu, http://www.inmemoriam.architektsarp.pl/pokaz/ wojciech_onitzch,4976, dostęp 04.05.2020). K. Raczyński miał także pośredni udział w powstaniu kościoła w Podkowie Leśnej. Kierowany przez niego Automobilklub Polski objął bowiem kuratelę nad tym przedsięwzięciem. Postarała się o to zapewne Halina Regulska, czołowa automobilistka, uczestniczka i zwyciężczyni szeregu rajdów, a prywatnie żona dyrektora „SiŚ’, zasiadająca w społecznym komitecie na rzecz budowy tego obiektu. Przyjęcie za patrona św. Krzysztofa (opiekuna podróżnych) dostarczyło odpowiedniego argumentu na rzecz włączenia się AP do akcji.

${ }^{65}$ Park, podobnie jak kościół, powstał nie w pierwotnie planowanym miejscu, dość odległym od centrum, ale na dwóch parcelach przylegających do przystanku kolejowego.

${ }^{66}$ AP Kielce, UW, OBiPP, sygn. 3777, s. 1.

${ }^{67}$ AP Kielce, UW, OBiPP, sygn. 3777, s. 31-32, 35.

68 AP Kielce, UW, OBiPP, sygn. 3777, s. 41. 


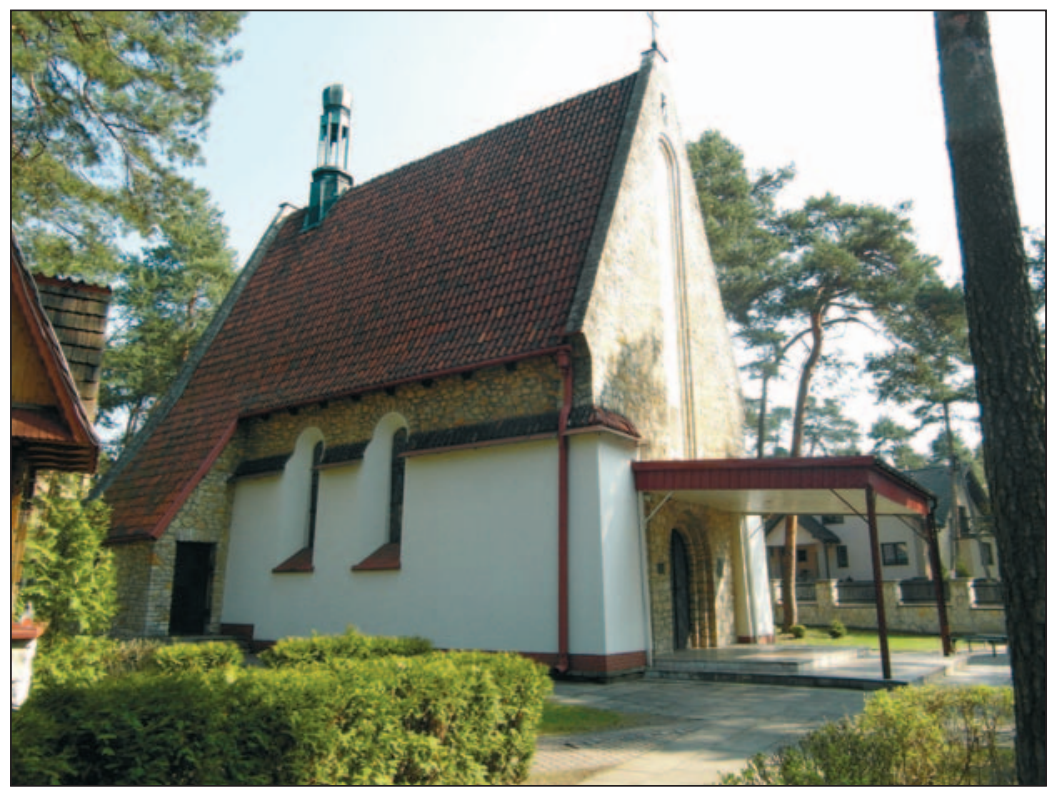

Ryc. 11. Kościółek w Kolonii Letniej Żarki, widok współczesny (fot. D. Malczewska-Pawelec)

Fig. 11. A church in Kolonia Letnia Żarki, the present condition (photo by D. Malczewska-Pawelec)

itp.), czytelni i bibliotek, otwieranie biur porady prawnej, pośrednictwa kupna i sprzedaży nieruchomości oraz wynajmu lokali, przeprowadzanie badań stanu i potrzeb Kolonii, opracowywanie w tym zakresie odpowiednich projektów i referatów, urządzanie bufetów, widowisk, gier, zabaw, koncertów i innych rozrywek dla członków i wprowadzonych gości69

Na pierwszym walnym zgromadzeniu organizacja przyjęła jako priorytetowe działania podjęcie starań o elektryfikację miejscowości oraz o doprowadzenie do niej szosy. Wspomniana urzędowa zwłoka spowodowała, iż rok 1938 został, z punktu widzenia aktywności Towarzystwa, stracony. Wymienione w statucie cele mogły znaleźć swoje częściowe chociażby urzeczywistnienie dopiero w kolejnym sezonie, przerwanym już jednak przez wybuch II wojny światowej.

Lokalem Stowarzyszenia pozostawało mieszczące się w Kolonii od 1932 r. biuro Zarządu Dóbr Żarki. Okoliczność ta sugeruje, iż przedsięwzięcie to nie było działaniem wymierzonym przeciwko hrabiemu, ale z pewnością w jakiejś mierze z nim uzgodnionym. Świadczy o tym także obecność w grupie inicjatywnej, a później także i w Zarządzie Towarzystwa, Jana Brylskiego, oddelegowanego ze Złotego Potoku urzędnika Raczyńskich ${ }^{70}$. Nie można zatem wykluczyć, iż inspiracja powołania Stowarzyszenia wyszła od samego Karola Raczyńskiego lub jego najbliższego otoczenia. W sytuacji bowiem ograniczonych możliwości hrabiego (finansowych, prawnych, urzędniczych) przy niewątpliwej jednocześnie chęci dalszego angażowania się na rzecz rozwoju Kolonii (czemu nieraz dawał konkretny, materialny wyraz) powstanie społecznej

69 AP Kielce, UW, OBiPP, sygn. 3777, s. 43.

${ }^{70}$ AP Kielce, UW, OBiPP, sygn. 3777, s. 42. Co więcej, wedle poufnych informacji, zebranych przez Starostwo Powiatowe w Zawierciu dla potrzeb Urzędu Wojewódzkiego w Kielcach, to właśnie Brylski (a nie wybrany na przewodniczącego Włodarski) miał być „główną sprężyną żywotności stowarzyszenia”. 


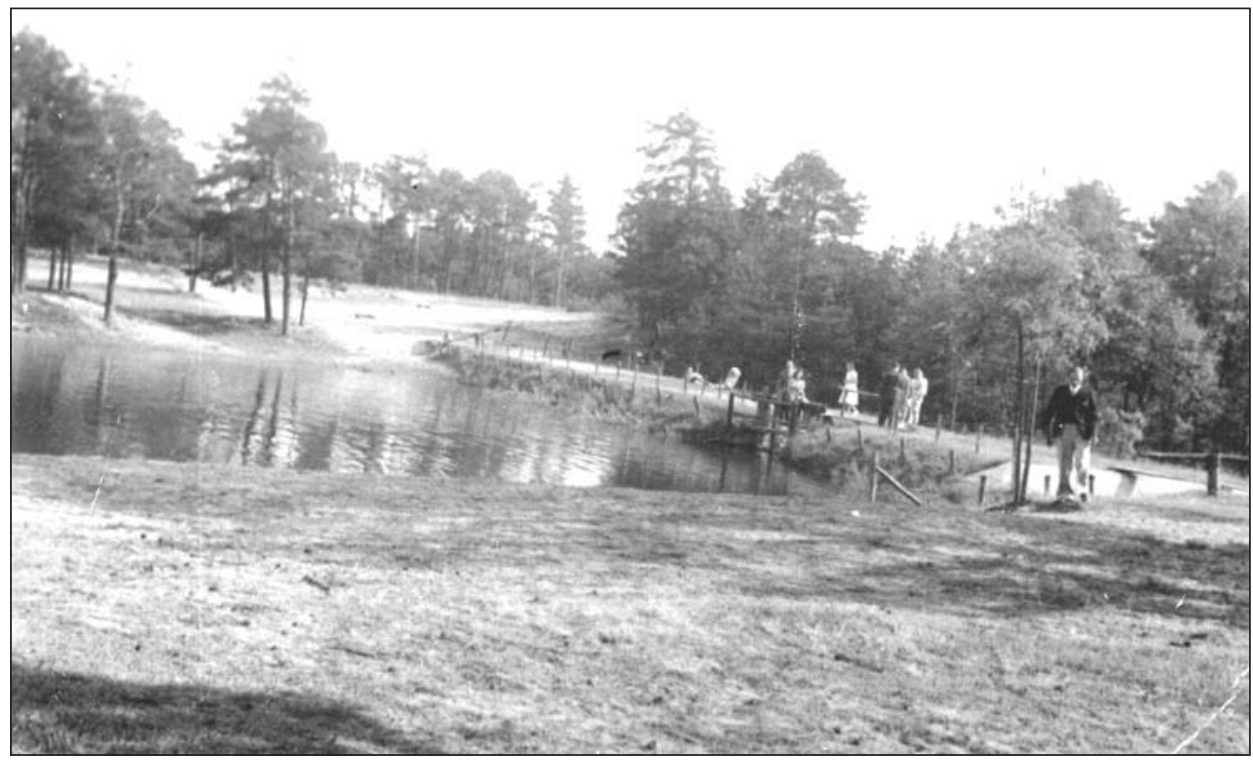

Ryc. 12. Kąpielisko leśne w Kolonii Letniej Żarki

(źródło: zbiory Towarzystwa Przyjaciół Żarek Letniska im. Hrabiny Stefanii Raczyńskiej)

Fig. 12. A bathing place in Kolonia Letnia Żarki (from the archive of the Association of the Friends of Żarki Letnisko)

organizacji posiadającej pewien ustawowy repertuar środków wpływu, nacisku i inicjatywy stanowić mogło cenne uzupełnienie lub też wzmocnienie starań podejmowanych przez właściciela żareckich dóbr. Oba podmioty, formalnie działające oddzielne, mogły mieć analogiczne cele i podejmować podobne wysiłki.

\section{Zakończenie}

Zestawienie procesu powstawania Podkowy Leśnej oraz Kolonii Letniej Żarki, dwóch inwestycji fundowanych w oparciu o pomysł „miasta-ogrodu”, umożliwiło ukazanie zarówno podobieństw, jak i różnic obu projektów. Do tych pierwszych należy bezsprzecznie zaliczyć reformę rolną z 1925 r., będącą tłem działań parcelacyjnych zarówno Stanisława Lilpopa, jak i Karola Raczyńskiego. Każdy z nich bowiem starał się uzyskać jak największą korzyść materialną z rozparcelowania nadwyżki ziemi określonej w ustawie. W obu przypadkach projekt utworzenia nowych osad zgodnych z koncepcją „miasta-ogrodu” stwarzał ku temu dogodne możliwości. W przypadku Raczyńskiego zatwierdzenie parcelacji pod takie właśnie przeznaczenie otwierało szansę sprzedaży dość sporych terenów leśnych (formalnie wyłączonych z zakresu ustawy) oraz dodatkowo zaliczenia ich w poczet wynikającej z reformy rolnej obowiązkowej redukcji posiadanego areału. Trzeba jednak podkreślić, iż zarówno właściciel brwinowskiego majątku, jak i dziedzic Złotego Potoku, traktowali projekt „miasta-ogrodu” poważnie, nie zaś instrumentalnie, tj. upatrując w nim jedynie element doraźnego marketingu i reklamy, co było dość powszechne w czasie wzmożonego podejmowania przedsięwzięć parcelacyjnych ${ }^{71}$.

${ }^{71}$ Nieodpowiedzialne, obliczone na szybki zysk parcelacje w okresie drugiej RP stały się przedmiotem licznych krytycznych artykułów zamieszczanych w ówczesnej specjalistycznej prasie, zob.: np. Różański S. 1934, s. 5; Toeplitz T. 1929, s. 12-14. 
Żadna z miejscowości nie osiągnęła do wybuchu drugiej wojny światowej docelowego kształtu. Na tempie ich rozwoju negatywnie odbił się światowy kryzys gospodarczy. Zdecydowanie mocniej wpłynął jednak na Kolonię Letnią Żarki z racji jej późniejszego startu, a tym samym ograniczonych możliwości wykorzystania czasów gospodarczego ożywienia przypadającego na lata 1926-1929. Nie bez znaczenia było także, że w Podkowie Leśnej zainwestowały swe środki prominentne i majętne osoby związane z kierownictwem spółek „SiŚS”. Ponadto bliskość stolicy zapewniała znacznie większą niż zagłębiowskie miasta liczbę potencjalnych nabywców nietanich bynajmniej działek. Biorąc pod uwagę rozwój infrastruktury wydaje się, iż oba „miasta-ogrody” pozostawały mniej więcej na tym samym poziomie, choć niejaką przewagę uzyskała podwarszawska Podkowa Leśna, dzięki doprowadzeniu energii elektrycznej (Kolonię zelektryfikowano dopiero po drugiej wojnie światowej). Jednak pod każdym innym względem skromniejsza nieco w swoich rozmiarach i „młodsza” Kolonia mogła się pochwalić podobnymi inwestycjami — parkiem, kościołem, lokalami gastronomicznymi, kilkoma pensjonatami, sklepikami, a nawet kortami tenisowymi. Brak prądu rekompensowała sobie niejako leśnym kąpieliskiem z plażą, które świetnie współgrało z jej rekreacyjno-letniskowym charakterem. Z podobieństw warto jeszcze wskazać, iż mieszkańcy (czasami tylko właściciele parcel) obu miejscowości założyli towarzystwa działające na rzecz wspólnoty, tym samym spełniając przewidywania Howarda o aktywizacji społecznej mieszkańców miast-ogrodów.

Z różnic na pierwszy plan wysuwa się kwestia odmiennych rozwiązań prawno-organizacyjnych przyjętych w celu realizacji idei miasta-ogrodu. Kolonię Letnią Żarki od początku tworzyła osoba fizyczna, Karol Raczyński, który jako jedyny właściciel parcelowanych terenów stał się też gwarantem prawidłowego, zgodnego z planistyczną wizją, rozwoju miejscowości. Inaczej, jak się okazało, ze stratą dla dochowania wierności pierwotnemu projektowi (zwłaszcza w odniesieniu do obszarów przeznaczonych na cele publiczne) rzecz się miała w przypadku Podkowy Leśnej. Tam początkowo kwestie związane z tworzeniem nowego osiedla leżały w gestii osoby prawnej, tj. specjalnie utworzonej w tym celu spółki z ograniczoną odpowiedzialnością, zaś po jej rozwiązaniu uległy częściowemu rozproszeniu. Właścicielami niekupionych jeszcze terenów stali się począwszy od 1928 r. niezwiązani żadnymi umowami pierwotny właściciel dóbr brwinowskich S. Lilpop (a po jego śmierci w 1930 r. spadkobiercy), SiŚ oraz BZSZ. Żaden z tych podmiotów nie był jednak szczególnie zainteresowany dalszymi inwestycjami, a jedynie w miarę szybką i zyskowną sprzedażą swojej puli działek.

Różnice widać również w charakterze poszczególnych miejscowości. Podkowa Leśna planowana była jako swego rodzaju przedmieście stolicy, z kolei Kolonia jako osada rekreacyjno-letniskowo-uzdrowiskowa ${ }^{72}$. Warunkowało to chociażby skład docelowej grupy mieszkańców, wielkość działek oraz skalę wyzwania marketingowego. Pierwsza z nich była atrakcyjna także dla ludzi młodych, czynnych zawodowo i dla rodzin z dziećmi, dzięki szybkiemu i dogodnemu połączniu komunikacyjnemu z Warszawą, umożliwiającemu pracę i edukację w stolicy. Zbyt duża odległość Kolonii Letniej od miast Zagłębia Dąbrowskiego (a także rzadziej kursujące pociągi) sprawiały, iż na stałe zamieszkanie decydowali się tam przeważnie emeryci. W związ-

72 Raczyńscy świetnie wykorzystali i twórczo zinterpretowali ramy prawne, jakie stworzyła im Ustawa o wykonaniu reformy rolnej oraz związane z nią akty wykonawcze i ministerialne wykładnie. W cytowanej już instrukcji parcelacyjnej z 1927 r. w części dotyczącej kolonii robotniczych i urzędniczych zakładano dwa odrębne warianty: powstanie kolonii przeznaczonych do stałego zamieszkiwania (czyli właściwe kolonie urzędnicze itp.) oraz kolonii letniskowych, uzdrowiskowych przeznaczonych do częściowego, okresowego zamieszkiwania. Każda z nich miała spełniać określone warunki (AP Kielce, OUZ, sygn. 2286, s. 34). Właściciele Złotego Potoku zaproponowali dla tworzonej przez siebie Kolonii Letniej Żarki swoiście „hybrydowy” kształt. Od początku planowana była bowiem zarówno jako docelowe miejsce życia dla pewnej grupy osób (zgodnie z duchem projektu „miasta-ogrodu”), jak i obszar czasowego pobytu dla szerszej populacji z uwagi na jego uzdrowiskowo-rekreacyjne walory. 
ku z tą specyfiką Kolonię silniej dotykał problem sezonowości (podobnie zresztą jak większość uzdrowisk), wpływający także na zakres i kierunki prowadzonych w niej inwestycji. Odmienne nieco przeznaczenie obu osiedli przekładało się też zapewne częściowo na rozmiary działek i ich cenę. W podwarszawskiej Podkowie wydzielono ich zdecydowanie więcej (biorąc oczywiście poprawkę na nieco rozleglejszy jej obszar), a ich wartość kilkakrotnie przewyższała cenę tych oferowanych w położonej w Jurze Kolonii. Przed właścicielem tej ostatniej stanęło też poważniejsze, jak można sądzić, wyzwanie reklamowe - skuteczne zachęcenie do kupna parceli w hipotetycznym (przynajmniej do połowy lat trzydziestych) „mieście-ogrodzie”, położonym w „szczerym lesie”73.

W zakresie odrębności wiele wskazuje na to, iż proces rozbudowy Kolonii Letniej Żarki przebiegał w lepszej atmosferze, jeżeli chodzi o relację parcelanta z mieszkańcami lub też nabywcami działek, niż miało to miejsce w Podkowie Leśnej. Nie są bowiem znane żadne oznaki niezadowolenia tamtejszej społeczności z działań inicjatorów i realizatorów projektu — hrabiowskiej pary Stefanii i Karola Raczyńskich. Co więcej, żywo zachowała się dobra pamięć o ich zasługach dla miejscowości. Nieco odmiennie kwestia ta przedstawiała się w drugim z opisywanych przez nas „miast-ogrodów”. Żale oraz pretensje mieszkańców z powodu zaniedbań, zaniechań i nieprawidłowości występujących przy rozbudowie Podkowy przedostawały się nawet na łamy prasy ${ }^{74}$. Można zaryzykować zatem twierdzenie, że dzięki nieprzerwanej opiece i asyście K. Raczyńskiego położona na prowincji żarecka kolonia miała być może nie gorsze szanse rozwoju w przyszłości niż bazująca na znacznych atutach swojego podstołecznego położenia Podkowa Leśna.

Wydaje się, iż powstawanie „miast-ogrodów” w drugiej Rzeczypospolitej, czy to w postaci przedmieść, czy też osad o charakterze rekreacyjnym, było przedsięwzięciem dość skomplikowanym i złożonym. Ich powodzenie zależało przede wszystkim od wysokiego stopnia zaangażowania fundatorów oraz niemałych nakładów finansowych potrzebnych na chociażby wstępne ich ukonstytuowanie. W przypadku braku któregoś z wymienionych czynników los tych oryginalnych koncepcji przestrzenno-architektonicznych stawał pod dużym znakiem zapytania. W czasach pełnych niepewności i zawirowań gospodarczych, cechujących się dość powszechnym deficytem kapitałowym, skazane były też niejako od początku na długie lata „dochodzenia” do swojej dojrzałości. Gdy stopień realizacji pierwotnego założenia był jednak zbyt mały, szybko zatracały one swój planowy charakter, „rozpływając się” w otaczającej przestrzeni lub też egzystowały w jakiejś bardzo skarłowaconej formie. Na tym tle pozytywnie wyróżniają się dwie analizowane realizacje, choć i w ich przypadku do osiągnięcia finalnego kształtu wiele jeszcze zabrakło. Stopień ich wdrożenia był już jednak na tyle zaawansowany, iż zdołał na trwałe ukształtować specyficzny charakter każdej z nich. Za miarodajny wskaźnik tej dojrzałości można uznać wykształcenie się wspólnotowych grup inicjatywnych, które podjęły się m.in. obowiązku „,stania na straży” przestrzenno-architektonicznego ładu analizowanych przez nas „miast-ogrodów”.

Adres Autorki:

dr hab. prof. UŚ Dorota Malczewska-Pawelec

Uniwersytet Śląski w Katowicach

ul. Bankowa 11

40-007 Katowice

dorota.malczewska-pawelec@us.edu.pl

https://orcid.org/0000-0003-0502-5306

73 Więcej na ten temat zob.: Malczewska-Pawelec D. 2017, s. 218-222.

74 Wróblewski B. 1995, s. 76-77. 


\section{BIBLIOGRAFIA}

\section{Źródła archiwalne}

AP Częstochowa [Archiwum Państwowe w Częstochowie], AGŻ [Akta gminy Żarki, 125], sygn. 248.

ASRM [Archiwum Sądu Rejonowego w Myszkowie], KW [księga wieczysta] Żarki 32.

AP Katowice [Archiwum Państwowe w Katowicach], SPZ [Starostwo Powiatowe w Zawierciu], sygn. 1196.

AP Kielce [Archiwum Państwowe w Kielcach], OUZ [Okręgowy Urząd Ziemski], sygn. 4317, 2286.

AP Kielce [Archiwum Państwowe w Kielcach], UW [Urząd Wojewódzki Kielecki I], OBiPP [Oddział Bezpieczeństwa i Porządku Publicznego — Referat Stowarzyszeń], sygn. 3777.

Muzeum [Muzeum Regionalne im. Zygmunta Krasińskiego w Złotym Potoku], Kopiał [Kopiał Głównego Zarządu Dóbr w Złotym Potoku]. 1930-1933 [za lata 1930-1933]; 1933-1934 [za lata 1933-1934].

Muzeum [Muzeum Regionalne im. Zygmunta Krasińskiego w Złotym Potoku], Księga Główna Rachunkowa [KGR]. 1932-1933 [za lata 1932-1933].

\section{Źródla i opracowania publikowane}

Begg Paul. 2010. Kuba Rozpruwacz. Historia kompletna, Warszawa.

Czyżewski Adam. 2001. Trzewia Lewiatana. Antropologiczna interpretacja utopii miasta-ogrodu, Kraków.

Czyżewski Adam. 2009. Trzewia Lewiatana. Miasta-ogrody i narodziny przedmieścia kulturalnego, Kraków.

Davies Norman. 2004. Europa. Rozprawa historyka z historia, Kraków.

Grzeszczuk-Brendel Hanna. 2012. Miasto do mieszkania. Zagadnienia reformy mieszkaniowej na przełomie XIX i XX wieku i jej wprowadzanie w Poznaniu w pierwszej połowie XX wieku, Poznań.

Leśniak-Rychlak Dorota. 2015. Nigdy nie należy być zbytnim optymistą, [w:] Howard E., Miasta-ogrody jutra, przeł. M. Trykozko, Warszawa, s. 7-24.

Łoza Stanisław. 1954. Architekci i budowniczowie w Polsce, Warszawa.

Malczewska-Pawelec Dorota. 2017. Idea uzdrowiska wśród sosen. Żarki hrabiostwa Raczyńskich, [w:] Wybrane elementy historii uzdrowisk polskich i niemieckich do 1945 r., red. B. Płonka-Syroka, A. Syroka, Wrocław, s. 209-230.

Miasta-Ogrody. 1912. Miasta-Ogrody, „Architekt”, R. XIII, z. 8, s. 82-83.

Michałowska Krystyna. 2002. Początki Podkowy, [w:] Wspomnienia Podkowian, Podkowa Leśna, s. 19-23.

Pustuła Zbigniew. 1972. Lilpop Stanisław (1817-1866), https://www.ipsb.nina.gov.pl/a/biografia/ stanislaw-lilpop (dostęp 04.05.2020).

Regulski Janusz. 1980. Blaski i cienie długiego życia, Warszawa.

Roszkowski Wojciech. 1986. Raczyński Karol Roger (1878-1946), [w:] Polski Słownik Biograficzny, t. XXIX/4, z. 123, s. 644.

Rozporządzenie. 1926. Rozporzadzenie Ministra Reform Rolnych z dnia 7 grudnia 1926 r. do ustawy o wykonaniu reformy rolnej, wydane w porozumieniu z Ministrami: Rolnictwa i Dóbr Państwowych, Skarbu oraz Sprawiedliwości, „Dziennik Ustaw”, 1927, nr 8, poz. 66.

Rozporządzenie. 1927. Rozporządzenie Rady Ministrów z dnia 5 stycznia 1927 r. o ustaleniu na rok 1927 wykazu imiennego nieruchomości ziemskich, podlegających wykupowi przymusowemu, „Dziennik Ustaw”, z 9 stycznia, poz. 13.

Różański Stanisław. 1934. Nowe osiedla w Polsce, „Dom Osiedle Mieszkanie”, R. VI, nr 7/8, s. 2-5.

Smolarkiewicz Władysław. 1938. Parafia św. Mikołaja B-pa i Kościót p.w. Św. Ap. Piotra i Pawła w Przybynowie (k/Żarek). Diecezji Częstochowskiej, Częstochowa.

Sokołowska-Moskwiak Joanna. 2011. „Idea miasta-ogrodu” na przykładach osiedli miast górnośląskich, Gliwice. 
Toeplitz Teodor. 1929. Przygotowanie terenów pod kolonizację podmiejską, „Osiedle Mieszkanie Dom”, nr 1, s. 12-14.

Ustawa. 1925. Ustawa z dnia 28 grudnia 1925 r. o wykonaniu reformy rolnej, „Dziennik Ustaw”, 1926, nr 1, poz. 1 .

Wróblewski Bogdan. 1995. Podkowa Leśna. Miasto-ogród do 1939 roku, Podkowa Leśna.

\section{Strony internetowe}

OAPL [Obywatelskie Archiwum Podkowy Leśnej], ZATPMOPL [Zespół Archiwum działalności Towarzystwa Przyjaciół Miasta-Ogrodu Podkowa Leśna], sygn. 13, http://mbc.cyfrowemazowsze. $\mathrm{pl} /$ dlibra/docmetadata?id=67121\&from=publication (dostęp 04.05.2020).

http://www.inmemoriam.architektsarp.pl/pokaz/waclaw_krzyzanowski,15184 (dostęp 04.05.2020). http://www.inmemoriam.architektsarp.pl/pokaz/wojciech_onitzch,4976 (dostęp 04.05.2020).

The realization of the idea of "garden cities" in inter-war Poland. Exemplified with Podkowa Leśna and Kolonia Letnia Żarki

The article presents two cases of parcellation in inter-war Poland based on the idea of the garden city, which resulted in the establishment of Podkowa Leśna near Warsaw and of Kolonia Letnia Żarki in the then Kielce voivodship. The introductory part outlines Ebenezer Howard's idea, which is an important point of reference for the two case studies. The analysis concerns the following issues: the circumstances of establishing the settlement, the formal, legal and organizational steps taken during the realization of the designs, the spatial arrangement of the settlements, the tempo of selling the plots and of new inhabitants' settling, the development of infrastructure before World War II and the evidenced involvement of the inhabitants. The final part points to similarities and differences between the two cases described, and draws some general conclusions about the opportunities, chances and challenges involved in such projects in inter-war Poland. It is highlighted that most of them were doomed to failure due to adverse economic conditions, land speculation and the irresponsible approach of those that parcelled out their land for sale. The two projects analysed stood out against such a background. Podkowa Leśna managed to keep its character mainly thanks to investments made in its early years (realized by the "Miasto-Ogród" company), while Kolonia - to the constant involvement and initiative of Karol Raczyński, the owner of the parcelled estate. In each of the two "garden cities" there was a association of the inhabitants, which took care of the settlement's development in line with the initial vision. 